\title{
The impact of IAS 36 on goodwill disclosure: Evidence of the write-offs and performance effects
}

\author{
Gabriele D'Alauro \\ University of Genoa, (Italy) \\ gdalauro@economia.unige.it
}

\section{Abstract}

Purpose: This paper aims at examining the quality of corporate disclosure about goodwill impairment and its relationship with goodwill write-offs and earnings performance, exploiting an accounting regulation that allows significant unverifiable estimates whilst requires a high level of information.

Design/methodology/approach: This study, based on a sample of Italian and British firms with market indications of goodwill impairment, verifies through a both univariate and multivariate analysis whether the level of disclosure is positively related to the magnitude of goodwill write-off and to earnings performance, using a self-constructed score of mandatory disclosure about goodwill impairment tests in accordance with IAS 36 requirements.

Findings: In a general context of insufficient information, we find that for Italian firms both the magnitude of goodwill write-offs and earnings performance are significantly and positively associated to the level of mandatory disclosure about goodwill impairment tests. For the British firms, as companies more used to impairment test rules, the data does not confirm any significant association.

Research limitations/implications: The objective of this study is to test the initial impact of IAS 36 in the first years of its application, selecting a sample of firms belonging to limited but significant activity sectors. Future research could usefully analyse a wider sample of firms, also extending the time period of analysis. In any 
case, the findings of our study are consistent with the insights of earnings management theory, suggesting that the subjectivity inherent in impairment test assumptions could be used opportunistically by managers.

Originality/value: This research investigates questions still relatively unexplored, concerning the effects of goodwill write-offs and accounting performance on corporate disclosure about goodwill impairment test. Based on this analysis, the study shows that corporate disclosure could be a "litmus paper" able to test the degree of good faith with which each firm has implemented IAS 36 requirements.

Keywords: Disclosure, Goodwill Write-offs, Accounting Performance, Corporate Governance, Earnings Management

Jel Codes: M41, M48

\section{Introduction}

There is an ongoing debate on the importance of goodwill accounting. The Financial Accounting Standards Board (FASB) has sought to improve the relevance of this issue by moving towards goodwill impairment rules with SFAS 142 - Goodwill and Other Intangible Assets (FASB, 2001). Similarly, IAS 36 - Impairment of Assets (IASB, 2004) eliminates goodwill amortization, requiring instead that goodwill be evaluated at least annually for possible impairment.

The shift from amortization to periodic reviews puts a new and continuous responsibility on business managers to determine the recoverable amount of goodwill and a new burden on auditors, regulators and investors to evaluate management determination (Hayn \& Hughes, 2006).

In the light of IAS 36 requirements, as well known, an impairment test is based on a chain of significant assumptions, with reference, for instance, to cash generating units identification, discount rates estimate, growth rates appraisal. Such a degree of allowable discretion, as earnings management theory predicts, could be used opportunistically by managers (Watts, 2003; Quagli \& Meini, 2007). On the other hand, the level of impairment disclosure required by IAS 36 is considerably high, regardless of whether goodwill write-offs are recorded or not.

In the general context of IAS introduction, it is well documented that companies do not necessarily comply with accounting standards mandatory disclosure (Tsalavoutas, 2011), as the existence of legislation and enforcing bodies does not guarantee compliance (Yeoh, 2005) 
and, even when disclosures are mandatory, firms still have some flexibility in the way they report the information (Chavent, Ding, Fu, Stolowy \& Wang, 2006; Chen \& Jaggi, 2000). As a consequence, our analysis aims at measuring compliance with IAS 36 mandatory disclosure during the first years of its implementation, determining a significant change in the accounting treatment of goodwill.

Particularly, using a sample of Italian and British listed firms with market indications of goodwill impairment, this paper examines whether the quality of disclosure about a goodwill impairment test is related to the magnitude of goodwill write-off.

We consider both Italian and British consolidated financial statements for the period 2006 2008, in order to check the initial impact of IAS 36 application for countries with a significantly different accounting tradition. OIC 24 - Intangible Assets (OIC, 2005) requires the systematic amortization of goodwill, while under FRS 10 - Goodwill and Intangible Assets (ASB, 1997) goodwill should be amortised only if it is regarded as having a limited useful life, otherwise it should not be amortised but reviewed for impairment at each period-end, providing an adequate disclosure in the notes to the accounts.

In a context of relevant unverifiable estimates which can seriously increase the likelihood of opportunistic behaviour, we assume that impairment disclosure could represent a relevant indicator of the degree of good faith with which management has implemented IAS 36 requirements on a goodwill impairment test. Accordingly, we test the positive relation between disclosure quality and magnitude of goodwill write-offs.

A separate but related issue is whether the level of disclosure is related to earnings performance. A few prior studies provide evidence of a positive relation between the general level of corporate disclosure and accounting performance indicators. Hence, we also test the positive association between the quality of specific disclosure about goodwill impairment and accounting performance of the firm.

Our analysis also allows to check the impact of the quality of corporate governance on the degree of corporate disclosure, by including specific variables connected with the composition of the board of directors and the activity of the audit committee, which should monitor the integrity of the financial statements of the company (Financial Reporting Council, 2006; Borsa Italiana, 2006).

This paper contributes to the existing research in several ways. Firstly it provides empirical evidence on the magnitude of goodwill write-offs, company profitability, the level of impairment disclosure and the quality of corporate governance with reference to a sample of firms of two countries with very different cultural contexts and accounting traditions. Secondly, 
it focuses on a question still relatively unexplored, finding a significant and positive relation between disclosure quality and goodwill write-offs. Thirdly, it studies the relation between corporate disclosure and earnings performance in a new context, that of goodwill accounting, providing evidence of the effects of accounting performance on the degree of corporate disclosure inherent in goodwill impairment tests.

This paper is organised as follows.

The next section provides background on related research. Section 3 develops the hypotheses for the study. Section 4 describes our sample selection and research design. In Section 5 the empirical results are shown. Section 6 discusses the results. In Section 7 additional analyses and robustness test are conducted. The final section draws conclusions.

\section{Previous Research}

There is a long stream of research that examines relevant issues related to goodwill accounting; in addition, the adoption of SFAS 142 and IFRS 36 has encouraged new studies on write-offs. Looking at the literature related to impairment of goodwill, there are three fundamental lines of research.

The first analyses the determinants of goodwill write-offs, in order to verify if managers, according to agency theory prediction, use discretion in accounting standards to manage their earnings opportunistically. Especially, these studies test if non-impairment decision increases in economic or financial characteristics that serve as proxies for greater unverifiable fair value based discretion.

The second related literature seeks to provide evidence on association between goodwill writeoffs, equity market values and stock returns. A subset of this literature examines the ability to predict goodwill impairment on the basis of accounting or financial performance ratios.

The third line of research, in some ways still relatively unexplored, aims to analyse the determinants of disclosure quality about goodwill impairment test. However, most of these studies only provide descriptive statistics about the content of corporate disclosure.

Overall, it should be added that the issues relating to these research areas are treated together in many works, as described below.

Beatty and Weber (2006) examine the factors affecting the decision to take an SFAS 142 write-off and the percentage of the goodwill that is actually written-off. With reference to previous studies (Watts \& Zimmerman, 1990; Francis, Hanna \& Vincent, 1996), they find empirical evidence that firms' debt contracting, bonus, turnover and exchange delisting 
incentives affect managers' decisions to accelerate or delay expense recognition. In particular, they argue that managers with longer tenures are more likely to have been involved in the acquisitions that generated that goodwill. The data confirms that, to avoid reputation costs, such long-tenure managers are less likely to take goodwill write-offs.

Ramanna (2008) studies the evolution of SFAS 142, which uses unverifiable fair-value estimates to account for acquired goodwill, in order to test what is argued in previous research (Holthausen \& Watts, 2001; Watts, 2003; Roychowdhury \& Watts, 2007). He assumes that FASB issues SFAS 142 in response to political pressure over its proposal to abolish pooling accounting, and the results are consistent with SFAS 142 impairment tests being due in part to firms opposed to abolishing pooling.

Another study of the same author, together with Watts (Ramanna \& Watts, 2012), finds a low frequency of goodwill write-offs in a sample of American firms with strong market indications of goodwill impairment (firms with book goodwill and two successive years of book to market ratios above one). The data does not confirm that the decision of avoiding impairment is due to management's possession of favourable private information. On the contrary, the authors find evidence that non-impairment is associated with agency-based motives: goodwill impairments decrease in CEO reputation and debt-covenant violation concerns. However, the results don't confirm a significant association between goodwill write-offs and firm capitalisation ratios.

Ahmed and Guler (2007) focus on the relationship between impairment of goodwill, stock returns and stock prices. In particular, contrary to Ramanna and Watts (2012), they find a significant negative association between goodwill write-offs and stock returns in the post SFAS 142 period. Furthermore, they find evidence that such association is higher for firms that have a high number of segments, suggesting that goodwill numbers are more reliable for firms with a high number of segments relative to firms with a low number of segments.

Bens, Heltzer and Segal (2007) document a negative and significant stock market reaction to unexpected goodwill write-offs. In particular, they find evidence that the market reaction is attenuated for firms with low information asymmetry, suggesting that the market impounds this information into price for these firms prior to the public announcement by the company. In contrast with Ahmed and Guler (2007), the authors find no variation in market based on the complexity of the firm's structure (their proxy is the number of reported segments): however, in this study the sample is restricted to the firms with magnitude of goodwill impairment higher than $5 \%$ of total assets. 
Hayn and Hughes (2006) find that the ability to predict goodwill impairment based on performance indicators and information provided in the financial statements is limited. This is also due to the fact that these are general indicators that pertain primarily to the firm as a whole rather than to a particular segment or reporting unit to which goodwill shall, from the acquisition date, be allocated. Indeed, certain characteristics of acquired companies such as the premium paid in the acquisition, the percentage of the purchase price assigned to goodwill and the use of stock as the primary mode of consideration, appear to contribute more to the prediction of goodwill write-offs than available disclosures on the acquired entity in the years subsequent to the acquisition.

With regard to impairment disclosure, Paananen (2008), using a random sample of companies from France, Germany and the United Kingdom, examines the comparability of fair value accounting of goodwill under IFRS. The data confirms, as expected, that large companies operating in United Kingdom, which is considered an environment with a relatively higher level of investor protection, are more likely to provide more disclosure on a goodwill impairment test. However, the author recognizes that the results should be interpreted cautiously since the study has inherent limitation of a small sample size and a simplistic method is used to measure disclosure levels among the sampled companies.

The study of Verriest and Gaeremynck (2009) investigates the determinants of goodwill impairment decisions, finding empirical evidence that companies with stronger corporate governance mechanism and also firms exhibiting better accounting and market performance are more likely to impair. The authors, according to Francis et al. (1996), argue that better performing firms are more likely to engage in goodwill impairment as the signal they send out to investors of a lower profitability is weaker and of lower importance, provided that these firms are financially healthy.

In the same study Verriest and Gaeremynck (2009) also examine the determinants of disclosure quality on goodwill impairment. However, they find that ownership structure and corporate governance quality have a weak impact on the degree of impairment disclosure. In addition, the data doesn't confirm the expected positive association between accounting performance indicators and the level of impairment disclosure.

There is also a more extensive research on the influence of earnings performance or earnings quality on the general level of mandatory or voluntary corporate disclosure, that is, disclosure not specifically inherent in goodwill impairment tests. In any case, some of these studies provide evidence of an increase in all types of disclosures during periods of increased earnings (Miller, 2002) and find that voluntary disclosure and earnings quality are positively related (Francis, Nanda \& Olsson, 2008). In a broader context, other works investigate how firm 
disclosure activity affects the relation between current annual stock returns, contemporaneous annual earnings and future earnings (Lundholm \& Myers, 2002) and examine the effect of voluntary disclosure on the use of discretionary accruals to smooth earnings and on the value relevance of earnings (Lapointe-Antunes, Cormier, Magnan \& Gay-Angers, 2006).

\section{Hypothesis Development}

The results of studies of goodwill write-offs determinants are generally mixed. Prior research does not find strong evidence on identifying specific factors able to have significant predictive ability for goodwill impairments. Indeed, analytical research provides conflicting predictions about how stock returns or accounting performance influence the magnitude of goodwill writeoffs.

This seems primarily due to the fact that the key indicators treated by most of literature pertain to the firm as a whole rather than to the specific cash generating unit to which each goodwill shall be allocated.

On the other hand, it should be noted that IAS 36 impairment tests allow significant unverifiable estimates which can seriously increase the likelihood of opportunistic disclosures. In estimating the recoverable amount of goodwill, management assesses the reasonableness of the assumption on which its current cash flow projections are based, with reference, for instance, to cash generating units identification, discount rates estimate, growth rates appraisal. In this context, managers could exploit the high degree of discretion in order to manage earnings, in line with the insights of earnings management theory (Watts, 2003; Quagli \& Meini, 2007).

Relating to this issue, a few prior studies find evidence that non-impairment is associated with agency-based motives and is increasing in financial characteristics, as number or size of reporting units and unverifiable net assets in reporting units, that serve as proxies for greater unverifiable fair value discretion.

However, the level of impairment disclosure required by IAS 36 is considerably high, regardless of whether goodwill write-offs are recorded or not. Firms have to provide detailed information in the notes to the financial statements on any significant assumption used to determine goodwill fair value or value in use.

Hence, disclosure requirements seem to act as a significant counterweight to the several profiles of subjectivity inherent in impairment test assumptions. On the other hand, a low level of disclosure provided by the firm could reveal earnings management. 
Prior research generally has not looked at the association between disclosure quality and magnitude of goodwill write-offs. This study will address this issue, in order to investigate the existence of an interrelation between mandatory disclosure in accordance with IAS 36, recording of goodwill impairments and earnings performance.

In a sample of Italian and British listed firms with market indications of goodwill impairment, we firstly assume a lower level of disclosure provided by the firm in case of non-impairment. Accordingly, we hypothesize a positive relation between disclosure quality and magnitude of goodwill write-offs.

Hypothesis $1(\mathrm{H} 1)$ :

"The level of impairment disclosure provided by firms with market indications of goodwill impairment is positively associated to the magnitude of goodwill write-offs".

Our second hypothesis, consistent with the group of studies that provide evidence on positive relation between the general level of corporate disclosure and accounting performance indicators, is the following.

Hypothesis $2(\mathrm{H} 2)$ :

"The level of impairment disclosure provided by firms with market indications of goodwill impairment is positively associated to earnings performance".

However, as discussed earlier, it should be noted that Italy and the United Kingdom are countries with very different cultural contexts and accounting traditions. In particular, only British firms have applied goodwill impairment tests before IAS 36 effective date, in accordance with FRS 10 requirements. As a result, we suppose that disclosure provided by British firms, as company more used to impairment test rules, is less influenced by goodwill write-offs and accounting performance.

Hypothesis $3(\mathrm{H} 3)$ :

"The association between impairment disclosure and goodwill write-offs and the association between impairment disclosure and accounting performance are higher for Italian firms compared to British firms". 


\section{Research Design}

\section{Sample Selection}

As noted in the literature review, the sample selection criteria adopted in previous related studies are not the same.

For instance, Bens et al. (2007) select firms with magnitude of goodwill impairment higher than $5 \%$ of total assets, Ramanna and Watts (2012) analyse only firms with two successive years of book to market ratios above one, Beatty and Weber (2006) restrict the sample to firms with a difference between the market and the book value of their equity that is less than their recorded goodwill, Paananen (2008) randomly selects firms with a positive gross value of goodwill.

In summary, most of the previous studies identify selection criteria, albeit variously configurable, in order to select firms with indication of likely goodwill impairment.

Similarly, in our research we analyse only firms that are expected to engage in goodwill impairment. We do this by investigating whether the firm market to book value (calculated before the effect of any goodwill impairment) is smaller than one or under the median of market to book value. The median of market to book value is calculated for each observation year and for each country.

The data used in the empirical tests is drawn from the consolidated financial statements of Italian and British sampled companies for the years 2006, 2007 and 2008. We choose this time period in order to investigate the initial impact of IAS 36 in the first years of its application: however, we exclude the year 2005 as the data could be influenced by the extraordinary effects caused by the transition to the different treatment of goodwill.

As discussed earlier, we consider both Italian and British companies in order to check the impact of IAS 36 application for countries with significantly different accounting traditions. Specifically, we choose, on the one hand, a country whose national accounting standard on intangible assets (the Italian OIC 24) is founded on the systematic amortization of goodwill, and, on the other hand, a country whose corresponding accounting standard (the British FRS 10 ) is based on the impairment test. 
The sample selection criteria are detailed in Table 1.

\begin{tabular}{|l|c|c|c|}
\cline { 2 - 4 } \multicolumn{1}{c|}{} & $\begin{array}{c}\text { Italian } \\
\text { companies }\end{array}$ & $\begin{array}{c}\text { British } \\
\text { companies }\end{array}$ & Total \\
\hline $\begin{array}{l}\text { First number of companies of } \\
\text { selected sectors }\end{array}$ & 42 & 39 & 81 \\
\hline $\begin{array}{l}\text { First number of sampled } \\
\text { consolidated financial } \\
\text { statements 2006 - 2008 }\end{array}$ & 126 & 117 & 243 \\
\hline Less: & -14 & -17 & -31 \\
\hline $\begin{array}{l}\text { Financial statements with zero } \\
\text { goodwill value }\end{array}$ & -52 & -48 & -100 \\
\hline $\begin{array}{l}\text { Financial statements with } \\
\text { market to book value both > } \\
\text { median and >1 }\end{array}$ & -1 & -1 & -2 \\
\hline $\begin{array}{l}\text { Financial statements with } \\
\text { negative book value of equity }\end{array}$ & 59 & 51 & 110 \\
\hline Final sample & & & \\
\hline
\end{tabular}

Table 1. Sample Selection Procedure

We firstly selected all Italian and British consolidated financial statements of companies:

- continuously listed from 2005 until 2008 in the stock market of their own country of origin (and not listed at the same time in the United States stock market);

- $\quad$ not reporting under IAS/IFRS before year 2005.

Then, we calculated for each activity sector the standard deviation of the number of firms belonging respectively to Italy and United Kingdom and we selected the sectors with own standard deviation equal to the median value. This in order to analyse the representative areas of the typical difference in terms of number of companies between the two countries. As a result, we identified the next five sectors with the same standard deviation (equal to 2.12 ):

- "Software and Computer Services";

- "Electronic and Electrical Equipment";

- "Automobiles and Parts";

- "Construction and Materials";

- "Household Goods and Home Construction".

It should be added, in order to evaluate the significance of the selected sectors, that they play a great importance within the gross domestic product in both countries, and concern both "old economy" and "new economy" areas. A significant number of large companies, listed on their respective stock markets, belong to these sectors, which are characterized by high interrelations among themselves and with other important sectors of national and international economy. Moreover, these areas are not affected by very high fluctuations in prices, and, finally, the selected sectors are not characterized by forms of monopolistic or monopsonistic market, but at mostly by oligopolistic configurations close to imperfect competition. 
The first number of sampled consolidated financial statements, referred to the years from 2006 to 2008, is 243; applying the selection criteria described in Table 1, we identify the final sample of 110 cases. This seems to be a justified reduction of the sample, having regard to the aim of this research. In addition, the final number of observations is aligned to the sample identifying in previous related studies, for instance the research of Ramanna and Watts (2012), reported to 124 observations, and the paper of Verriest and Gaeremynck (2009), focused on 47 statements.

We made a direct reading of each consolidated financial statements, without the use of any database, also in order to analyse the quality of disclosure about the goodwill impairment test reported in the notes to the accounts.

\section{Empirical Models}

In order to find evidence of our research hypotheses, we firstly develop a disclosure model concerning a goodwill impairment test. Disclosure is defined here as consisting of mandatory items of information provided in the notes to the consolidated financial statements in accordance with the requirements of IAS 36.

Table 2 describes ten items identified to measure corporate quality disclosure: the approach to scoring items is dichotomous in that an item scores one if disclosed and zero otherwise.

\begin{tabular}{|c|l|}
\hline Score & \multicolumn{1}{c|}{ Requirement } \\
\hline 1 & Identification of each cash generating unit (CGU) over which goodwill is allocated \\
\hline 1 & Goodwill allocation to CGUs \\
\hline 1 & No changes in CGUs identification or in goodwill allocation to CGUs since the previous year \\
\hline 1 & Information on the numbers of years covered by the budgets \\
\hline 1 & $\begin{array}{l}\text { Information on the growth rate used to extrapolate cash flow projections beyond the period } \\
\text { covered by the budgets }\end{array}$ \\
\hline 1 & $\begin{array}{l}\text { Information on the numbers of years over which management has projected cash flow based } \\
\text { on financial budgets }\end{array}$ \\
\hline 1 & Information on the discount rates applied to the cash flow projections \\
\hline 1 & Differentiation of the discount rates applied to each CGUs \\
\hline 1 & $\begin{array}{l}\text { Recourse to external sources of information or appraisal to verify the assumptions on which } \\
\text { management has founded its impairment test }\end{array}$ \\
\hline 1 & Sensitivity analysis for the units' recoverable amount \\
\hline 0 & Minimum score \\
\hline 10 & Maximum score \\
\hline
\end{tabular}

Table 2. Disclosure Score

Hence the maximum a company could achieve is 10 and the minimum zero.

The dichotomous method gives equal weight to the individual items required to be disclosed by the standard (Cooke, 1989; Cooke, 1992; Hossain, Tan \& Adams, 1994) and therefore it enables to reduce the degree of subjectivity in the evaluation of mandatory information provided by each firm (Tsalavoutas, Evans \& Smith, 2010). 
The number of items is limited, but it results from the scope of our study, which concentrates on a single topic, that is disclosure regarding goodwill impairment tests. In addition, our number of requirements is aligned to the number of items identifying in some previous disclosure studies, for instance 11 items (Tai, Au-Yeung, Kwok \& Lau, 1990), 9 items (Prencipe, 2004), 14 items (Chavent et al., 2006), 6 items (Deumes \& Knechel, 2008), 12 items (Greco, 2010).

In short, our items refer to information about cash generating units, identification and allocation of goodwill, as well as each key assumption used by management to measure units' recoverable amount, including information on recourse to external source of information and sensitivity analysis.

All the sampled firms have applied the "value in use" method in order to evaluate the recoverable amount of own goodwill.

\begin{tabular}{|l|l|}
\hline Variable & \multicolumn{1}{|c|}{ Definition } \\
\hline DISC & Score disclosure (from 0 to 10) concerning goodwill impairment test (see table 2) \\
\hline IMP / AST & $\begin{array}{l}\text { Goodwill impairment scaled by total assets (calculated before the effect of goodwill } \\
\text { impairment) }\end{array}$ \\
\hline IMP / EQT & $\begin{array}{l}\text { Goodwill impairment scaled by equity (calculated before the effect of goodwill } \\
\text { impairment) }\end{array}$ \\
\hline IMP / GDW & $\begin{array}{l}\text { Goodwill impairment scaled by goodwill (calculated before the effect of goodwill } \\
\text { impairment) }\end{array}$ \\
\hline ROE & $\begin{array}{l}\text { Profit (loss) for year (calculated before the effect of goodwill impairment) scaled by } \\
\text { equity (calculated before the effect of goodwill impairment) }\end{array}$ \\
\hline AVG.ROE & Average ROE in the period 2005 - 2008 \\
\hline A.C. MEET. & Number of meetings of the audit committee held in year \\
\hline A.C.IND.DIR. & $\begin{array}{l}\text { Number of independent directors members of the audit committee scaled by total } \\
\text { number of directors }\end{array}$ \\
\hline SIZE & Natural logarithm of total assets \\
\hline YEAR.06 & Dummy variable set to one if the case concerns the year 2006 \\
\hline YEAR.07 & Dummy variable set to one if the case concerns the year 2007 \\
\hline YEAR.08 & Dummy variable set to one if the case concerns the year 2008 \\
\hline SECT.A & $\begin{array}{l}\text { Dummy variable set to one if the case concerns the sector A "Software and Computer } \\
\text { Services" }\end{array}$ \\
\hline SECT.B & $\begin{array}{l}\text { Dummy variable set to one if the case concerns the sector B "Electronic and Electrical } \\
\text { Equipment" }\end{array}$ \\
\hline SECT.C & Dummy variable set to one if the case concerns the sector C "Automobiles and Parts" \\
\hline SECT.D & $\begin{array}{l}\text { Dummy variable set to one if the case concerns the sector D "Construction and } \\
\text { Materials" }\end{array}$ \\
\hline SECT.E & $\begin{array}{l}\text { Dummy variable set to one if the case concerns the sector E "Household Goods and } \\
\text { Home Construction" }\end{array}$ \\
\hline COUNTRY & Dummy variable set to one if the case concerns Italian companies \\
\hline
\end{tabular}

Table 3. Variable Definitions

Table 3 includes the definitions of all variables used in this study, which apply to disclosure level (DISC), goodwill write-offs, alternative ratios of company profitability, corporate governance variables and firm size. Most of the control variables have been commonly used in prior disclosure research studies (Cooke, 1991; Forker, 1992; Hossain, Tan \& Adams, 1994; 
Wallace, Naser \& Mora, 1994; Wallace \& Naser, 1995; Chen \& Jaggi, 2000; Eng \& Mak, 2003; Cerbioni \& Parbonetti, 2007).

In particular:

- to ensure the robustness of the results, three different scalars are used in order to measure the goodwill impairment loss - total assets (IMP / AST), equity (IMP / EQT) and goodwill (IMP / GDW) - all calculated at financial year-end before the effect of any goodwill impairment;

- the return on equity ratio (ROE), measured at financial year-end, represents the company profitability in the period;

- the company profitability is also measured by the average value of return on equity ratio (AVG.ROE), calculated with reference to the period from 2005 to 2008;

- the corporate governance related variables are represented by the number of meetings of the audit committee held in year (A.C.MEET.) and the number of independent directors members of the audit committee scaled by total number of directors (A.C.IND.DIR.);

- the firm size is given in the natural logarithm of total assets (SIZE).

The dummy variables refer to each year (from YEAR.06 to YEAR.08) and each sector (from SECT.A to SECT.E) considered in this study.

Consequently, we firstly examine a series of descriptive statistics arising from the financial statements reviewed, using appropriate tests of significance in order to obtain early feedback to our assumptions.

Subsequently, correlation analysis will be done through the construction of Pearson correlation matrices, checking positive correlations between corporate disclosure and goodwill impairment as well as earnings performance.

Finally, we test the fundamental assumptions with a multivariate analysis, using a series of multiple linear regressions that are introduced below.

Multiple linear regression - Model 1:

DISC $=a+b_{1}$ IMP/AST $+b_{2}$ ROE $+b_{3}$ A.C.MEET. $+b_{4} A . C . I N D . D I R .+b_{5}$ SIZE $+b_{6}$ YEAR.07 + $b_{7}$ YEAR.08 + b $_{8}$ SECT.A + b ${ }_{9}$ SECT.B $+b_{10}$ SETC.C $+b_{11}$ SECT.D + $b_{12}$ COUNTRY $+e$ 
Multiple linear regression - Model 2:

DISC $=a+b_{1}$ IMP/EQT $+b_{2}$ ROE $+b_{3}$ A.C.MEET $+b_{4}$ A.C.IND.DIR. + $b_{5}$ SIZE + b 6 YEAR.07 + $b_{7}$ YEAR.08 $+b_{8}$ SECT.A + $b_{9}$ SECT.B $+b_{10}$ SETC.C $+b_{11}$ SECT.D $+b_{12}$ COUNTRY + e

Multiple linear regression - Model 3:

DISC $=a+b_{1}$ IMP/GDW $+b_{2}$ ROE $+b_{3}$ A.C.MEET. $+b_{4}$ A.C.IND.DIR $+b_{5}$ SIZE $+b_{6}$ YEAR.07 + $b_{7}$ YEAR. $08+b_{8}$ SECT.A + $b_{9}$ SECT.B $+b_{10}$ SETC.C $+b_{11}$ SECT.D + $b_{12}$ COUNTRY + e

Multiple linear regression - Model 4:

DISC $=a+b_{1}$ IMP/AST $+b_{2}$ AVG.ROE $+b_{3} A . C . M E E T .+b_{4} A . C . I N D . D I R .+b_{5}$ SIZE $+b_{6}$ YEAR.07 $+b_{7}$ YEAR.08 + b $_{8}$ SECT.A + $b_{9}$ SECT.B $+b_{10}$ SETC.C $+b_{11}$ SECT.D + $b_{12}$ COUNTRY + e

Multiple linear regression - Model 5:

DISC $=a+b_{1}$ IMP/EQT $+b_{2}$ AVG.ROE $+b_{3}$ A.C.MEET. $+b_{4}$ A.C.IND.DIR. $+b_{5}$ SIZE + b 6 YEAR.07 $+b_{7}$ YEAR.08 + $b_{8}$ SECT.A + $b_{9}$ SECT.B $+b_{10}$ SETC.C $+b_{11}$ SECT.D + $b_{12}$ COUNTRY + e

Multiple linear regression - Model 6:

DISC $=a+b_{1}$ IMP/GDW $+b_{2}$ AVG.ROE $+b_{3} A . C . M E E T .+b_{4} A . C . I N D . D I R .+b_{5}$ SIZE $+b_{6}$ YEAR.07 $+b_{7}$ YEAR.08 $+b_{8}$ SECT.A + $b_{9}$ SECT.B $+b_{10}$ SETC.C $+b_{11}$ SECT.D + $b_{12}$ COUNTRY + e

The level of disclosure is the dependent variable regression of the six functions above, which differ in the choice of independent variables likely to express the extent of impairment of goodwill and the corporate profitability.

We will indicate below the results of further regressions, calculated after carrying alternatives substitutions of dummy variables not yet included to assure the accuracy of the issues, namely the dummy variable for the year 2006 (YEAR.06) and the dummy variable for the sector E (SECT.E).

Goodwill impairment is scaled to total assets in Model 1 and Model 4, equity in Model 2 and Model 5, goodwill in Model 3 and Model 6. In Models 1, 2 and 3 the economic performance is represented by the return on equity of the correspondent year, whilst in Models 4, 5 and 6 ROE it is calculated as an average value for the whole period from 2005 until 2008.

The coefficient on goodwill impairment $\left(b_{1}\right)$ and the coefficient on corporate profitability $\left(b_{2}\right)$ are expected to be positive (see, respectively, $\mathrm{H}_{1}$ and $\mathrm{H}_{2}$ ) and greater (see $\mathrm{H}_{3}$ ) with respect to the Italian cases. 
Furthermore, it is expected that the coefficient on size $\left(b_{5}\right)$ is positive, since usually the costs of disclosure decrease with increasing firm size (Hossain, Perera \& Rahman, 1995).

Concerning the issue of corporate governance, with regard to the scope of our study we selected a variable related to the level of activity of the audit committee, as its role and its responsibility include monitoring the integrity of the financial statements of the company (Sierra Garcia, Ruiz Barbadillo \& Orta Perez, 2012). A few previous studies provide empirical evidence of the positive association between the level of voluntary disclosure and the number of meetings held by the audit committee (Menon \& Williams, 1994; Karamanou \& Vafeas, 2005; Greco, 2010), so we predict a positive sign of the corresponding coefficient $\left(b_{3}\right)$.

In a broader context, with reference to the association between disclosure and corporate governance variables, the findings emerging from prior related research are not the same.

In fact empirical studies, mainly in the context of voluntary disclosure, show controversial results, in particular regarding the impact of independent directors.

Some works noted that the proportion of independent directors affects the quality of mandatory disclosure (Chen \& Jaggi, 2000) while other analyses found no association between the two variables (Forker, 1992). A recent line of research only considers "qualified" classes of independent directors, for instance represented by those directors defined as community influential board members (Michelon \& Parbonetti, 2012), showing positive associations with the level of voluntary disclosure.

Hence, we similarly consider in our analysis just the independent directors with an "active role", identified by membership of the audit committee, assuming a positive sign of the corresponding coefficient $\left(b_{4}\right)$.

Finally, we expect the level of disclosure to be significantly affected by the year as well as the sector (Cooke, 1992). With regard to variables related to years 2006 to 2008, it is assumed that the intensity of association to the level of disclosure is chronologically increasing, indicating a positive trend of progressive assimilation, especially for Italian companies, of the innovative provisions of IAS 36. 


\section{Results}

\section{Descriptive Statistics and Correlation Analysis}

As noted earlier, there are 110 observations meeting our sample criteria. Of these, as shown in Table 4, only $25 \%$ record goodwill impairment. Given our sample-selection criteria (market to book value below one or below median), the relatively low frequency of impairment suggests that IAS 36 is not so effective in generating timely write-offs.

\begin{tabular}{|l|c|c|c|c|c|c|}
\cline { 2 - 7 } \multicolumn{1}{c|}{} & \multicolumn{2}{c|}{ Italian cases } & \multicolumn{2}{c|}{ British cases } & \multicolumn{2}{c|}{ Total } \\
\cline { 2 - 7 } \multicolumn{1}{c|}{} & $\boldsymbol{n}$ & $\%$ & $\boldsymbol{n}$ & $\%$ & $\boldsymbol{n}$ & $\%$ \\
\hline No goodwill impairment & 46 & $78 \%$ & 37 & $73 \%$ & 83 & $75 \%$ \\
\hline Goodwill impairment & 13 & $22 \%$ & 14 & $27 \%$ & 27 & $25 \%$ \\
\hline Total & 59 & $100 \%$ & 51 & $100 \%$ & 110 & $100 \%$ \\
\hline
\end{tabular}

The chi-square statistic for the table has a p-value of 0.510

Table 4. Frequency of Goodwill Impairments

The frequency of goodwill non-impairment in the Italian sample (59 cases) is $78 \%$, while in the British sample (51 cases) the frequency is $73 \%$. The chi-square statistic for the comparison of impairment frequency across firm country is not statistically significant ( $p$-value of 0.510 ).

Table 5 presents some descriptive statistics for all the variables, with reference to the Italian and British companies.

In Panel 5A we report on the results among sampled Italian cases, equal to 59. The mean value of disclosure score is 5.5 , with an oscillation between the minimum possible score (equal to 0 ) to the maximum possible score (equal to 10 ).

The average amount of goodwill write-offs, in terms of total assets, is $0.2 \%$, reaching a maximum value of $9 \%$. In relation to equity, the mean value of goodwill impairment is $1.3 \%$ and records very high peaks, at $66.7 \%$ of equity. Moreover, the mean value of goodwill writeoffs related to book value of goodwill is $0.6 \%$, with a relevant maximum value equal to $14.9 \%$.

Subsequent Panel 5B reproduces the same descriptive statistics for the British cases, equal to 51 . The mean value of disclosure score is 5.0 ; the corresponding median value is equal to 5 and the maximum score reaches 8 .

The average amount of goodwill impairment, scaled by total assets, is $0.9 \%$, reaching a maximum value of $14.4 \%$. In terms of equity, the mean value of goodwill impairment is $1.8 \%$, with a maximum value equal to $26 \%$. Moreover, the median value of goodwill write-offs related to book value of goodwill is $7.0 \%$ : it is noticeable that the maximum value is $100 \%$. 


\begin{tabular}{|c|c|c|c|c|c|}
\hline \multicolumn{6}{|c|}{ Panel 5A: Italian Companies } \\
\hline Variable & Mean & Median & Minimum & Maximum & $\begin{array}{l}\text { Standard } \\
\text { deviation }\end{array}$ \\
\hline DISC & 5.475 & 6.000 & 0.000 & 10.000 & 2.615 \\
\hline \multicolumn{2}{|l|}{ IMP / AST } & 0.000 & 0.000 & 0.090 & 0.012 \\
\hline \multicolumn{2}{|l|}{ IMP / EQT } & 0.000 & 0.000 & 0.667 & 0.087 \\
\hline IMP / GDW & 0.006 & 0.000 & 0.000 & 0.149 & 0.022 \\
\hline ROE & 0.059 & 0.070 & -0.430 & 0.260 & 0.115 \\
\hline AVG.ROE & -0.033 & 0.071 & -5.274 & 0.208 & 0.700 \\
\hline A.C.MEET. & 3.373 & 3.000 & 0.000 & 10.000 & 2.399 \\
\hline A.C.IND.DIR. & 0.221 & 0.222 & 0.000 & 0.429 & 0.118 \\
\hline SIZE & 13.427 & 12.990 & 10.837 & 16.323 & 1.578 \\
\hline \multicolumn{6}{|l|}{$n=59$} \\
\hline \multicolumn{6}{|c|}{ Panel 5B: British Companies } \\
\hline Variable & Mean & Median & Minimum & Maximum & $\begin{array}{l}\text { Standard } \\
\text { deviation }\end{array}$ \\
\hline DISC & 4.980 & 5.000 & 0.000 & 8.000 & 2.549 \\
\hline \multicolumn{2}{|l|}{ IMP / AST } & 0.000 & 0.000 & 0.144 & 0.030 \\
\hline \multicolumn{2}{|l|}{ IMP / EQT } & 0.000 & 0.000 & 0.260 & 0.056 \\
\hline IMP / GDW & 0.070 & 0.000 & 0.000 & 1.000 & 0.211 \\
\hline ROE & 0.091 & 0.099 & -0.181 & 0.472 & 0.107 \\
\hline \multicolumn{2}{|l|}{ AVG.ROE } & 0.109 & -0.500 & 1.063 & 0.270 \\
\hline \multicolumn{2}{|l|}{ A.C.MEET. } & 4.000 & 2.000 & 6.000 & 1.146 \\
\hline \multirow{2}{*}{ A.C.IND.DIR. } & 0.406 & 0.400 & 0.200 & 0.625 & 0.101 \\
\hline & 12.716 & 12.948 & 8.645 & 15.550 & 1.764 \\
\hline \multicolumn{6}{|l|}{$n=51$} \\
\hline \multicolumn{6}{|c|}{ Panel 5C: Italian and British Companies } \\
\hline \multirow[t]{2}{*}{ Variable } & $\begin{array}{c}\text { Italian cases } \\
(n=59)\end{array}$ & \multicolumn{2}{|c|}{$\begin{array}{c}\text { British cases } \\
(n=51)\end{array}$} & $\begin{array}{l}\text { Difference in } \\
\text { mean value }\end{array}$ & t-statistic a \\
\hline & Mean & Me & & & \\
\hline DISC & 5.475 & & 4.980 & 0.495 & 1.002 \\
\hline IMP / AST & 0.002 & & 0.009 & -0.007 & 1.619 \\
\hline IMP / EQT & 0.013 & & 0.018 & -0.005 & 0.398 \\
\hline IMP / GDW & 0.006 & & 0.070 & -0.064 & $* * 2.152$ \\
\hline ROE & 0.059 & & 0.091 & -0.032 & 1.482 \\
\hline AVG.ROE & -0.033 & & 0.163 & -0.196 & 1.985 \\
\hline A.C.MEET. & 3.373 & & 3.647 & -0.274 & 0.781 \\
\hline A.C.IND.DIR. & 0.221 & & 0.406 & -0.185 & $* * * 8.854$ \\
\hline SIZE & 13.427 & & 12.716 & 0.711 & $* * 2.211$ \\
\hline
\end{tabular}

${ }^{a}$ Significantly different at the 0.10 level $(*), 0.05$ level $\left(^{* *}\right)$ or the 0.01 level (***).

Table 5. Descriptive Statistics

Panel 5C provides a comparison between the mean values of each variable, with reference, respectively, to the Italian and British cases.

In particular:

- the mean score of disclosure among the Italian sample (equal to 5.5) is statistically indistinguishable from the correspondent mean value among the British sample (equal to 5.0$)$; 
- the mean values of goodwill write-offs scaled by goodwill and of number of independent directors members of the audit committee scaled by total number of directors, are significantly greater for the British cases;

- the mean value of firm size is significantly greater for the Italian cases.

Of particular interest, the difference in terms of independent directors proportion is highly significant, as the percentage equal to $22.1 \%$ for the Italian cases rises to $40.6 \%$ with reference to the British observations.

Table 6 reports on the association between goodwill impairment and disclosure.

\begin{tabular}{|c|c|c|c|c|}
\hline \multicolumn{5}{|c|}{ Panel 6A: Italian companies - Total cases } \\
\hline Variable & $\begin{array}{c}\text { Cases without } \\
\text { goodwill impairment } \\
(n=46)\end{array}$ & $\begin{array}{c}\text { Cases with } \\
\text { goodwill impairment } \\
(n=13)\end{array}$ & $\begin{array}{l}\text { Difference } \\
\text { in mean } \\
\text { value }\end{array}$ & t-statistic ${ }^{a}$ \\
\hline & Mean & Mean & & \\
\hline DISC & 5.174 & 6.538 & -1.364 & $2.457 * * *$ \\
\hline \multicolumn{5}{|c|}{ Panel 6B: British companies - Total cases } \\
\hline Variable & $\begin{array}{c}\text { Cases without } \\
\text { goodwill impairment } \\
(n=37)\end{array}$ & $\begin{array}{c}\text { Cases with } \\
\text { goodwill impairment } \\
(n=14)\end{array}$ & $\begin{array}{c}\text { Difference } \\
\text { in mean } \\
\text { value } \\
\end{array}$ & t-statistic ${ }^{a}$ \\
\hline & Mean & Mean & & \\
\hline DISC & 5.297 & 4.143 & 1.154 & 1.364 \\
\hline \multicolumn{5}{|c|}{ Panel 6C: Italian and British companies - Cases without goodwill impairment } \\
\hline Variable & $\begin{array}{l}\text { Italian companies } \\
(n=46)\end{array}$ & $\begin{array}{l}\text { British companies } \\
\qquad(n=37)\end{array}$ & $\begin{array}{l}\text { Difference } \\
\text { in mean } \\
\text { value }\end{array}$ & t-statistic ${ }^{a}$ \\
\hline & Mean & Mean & & \\
\hline DISC & 5.174 & 5.297 & -0.123 & 0.215 \\
\hline \multicolumn{5}{|c|}{ Panel 6D: Italian and British companies - Cases with goodwill impairment } \\
\hline Variable & $\begin{array}{c}\text { Italian companies } \\
(n=13)\end{array}$ & $\begin{array}{l}\text { British companies } \\
\qquad(n=14)\end{array}$ & $\begin{array}{c}\text { Difference } \\
\text { in mean } \\
\text { value } \\
\end{array}$ & t-statistic ${ }^{a}$ \\
\hline & Mean & Mean & & \\
\hline DISC & 6.538 & 4.143 & 2.395 & $2.874 * * *$ \\
\hline
\end{tabular}

${ }^{a}$ Significantly different at the 0.10 level (*), 0.05 level (**) or the 0.01 level (***).

Table 6. Goodwill Impairment and Disclosure

Panel 6A shows that the mean score of disclosure for the Italian sampled firms is significantly greater (at the 0.01 level) with reference to the cases with goodwill impairment: this first finding is consistent with the positive assumed association between goodwill write-offs and level of disclosure.

In contrast, as shown in Panel 6B, the level of disclosure among the British cases with goodwill write-offs is statistically indistinguishable from the mean value of non-impairing observations.

Moreover, Panel $6 \mathrm{C}$ reports that the difference in mean value of Italian and British disclosure 
score is not significant in non-impairing cases, while Panel 6D shows that the difference in mean score of disclosure among the Italian cases with goodwill write-offs is significantly (at the 0.01 level) greater than the mean value among the British impairment observations.

Table 7 provides Pearson correlation coefficients between variables for the Italian and British cases.

\begin{tabular}{|c|c|c|c|c|c|c|c|c|c|}
\hline \multicolumn{10}{|c|}{ Pearson correlation coefficients between variables } \\
\hline Variable & Disc & $\begin{array}{c}\text { Imp / } \\
\text { Ast }\end{array}$ & $\begin{array}{c}\text { Imp / } \\
\text { Eqt }\end{array}$ & $\underset{\text { Gdw }}{\operatorname{Imp} /}$ & Roe & $\begin{array}{l}\text { Avg. } \\
\text { Roe }\end{array}$ & $\begin{array}{c}\text { A.C. } \\
\text { Meet. }\end{array}$ & $\begin{array}{l}\text { A.C.Ind } \\
\text {.Dir. }\end{array}$ & Size \\
\hline DISC & 1.00 & & & & & & & & \\
\hline IMP / AST & 0.03 & 1.00 & & & & & & & \\
\hline IMP / EQT & 0.10 & 0.77 & 1.00 & & & & & & \\
\hline IMP / GDW & 0.00 & 0.66 & 0.43 & 1.00 & & & & & \\
\hline ROE & 0.12 & -0.07 & -0.03 & -0.13 & 1.00 & & & & \\
\hline AVG.ROE & 0.15 & 0.06 & 0.07 & 0.05 & 0.25 & 1.00 & & & \\
\hline A.C.MEET. & 0.07 & 0.17 & 0.20 & 0.05 & -0.08 & -0.02 & 1.00 & & \\
\hline A.C.IND.DIR. & -0.14 & 0.22 & 0.15 & 0.28 & 0.00 & 0.07 & 0.26 & 1.00 & \\
\hline SIZE & 0.35 & -0.21 & -0.17 & -0.13 & 0.14 & -0.09 & 0.18 & -0.31 & 1.00 \\
\hline YEAR.06 & -0.12 & 0.05 & 0.10 & -0.09 & 0.06 & -0.13 & -0.13 & -0.05 & 0.03 \\
\hline YEAR.07 & -0.09 & -0.14 & -0.13 & -0.15 & 0.22 & 0.05 & -0.07 & 0.03 & 0.03 \\
\hline YEAR.08 & 0.20 & 0.09 & 0.03 & 0.23 & -0.26 & 0.07 & 0.19 & 0.02 & -0.05 \\
\hline SECT.A & -0.08 & 0.30 & 0.28 & 0.11 & -0.10 & 0.12 & 0.18 & 0.28 & -0.41 \\
\hline SECT.B & 0.22 & -0.12 & -0.10 & -0.12 & 0.02 & 0.06 & -0.12 & 0.02 & -0.22 \\
\hline SECT.C & 0.30 & -0.08 & -0.07 & -0.07 & -0.13 & -0.30 & 0.07 & -0.05 & 0.37 \\
\hline SECT.D & -0.15 & -0.12 & -0.10 & -0.08 & 0.13 & 0.01 & -0.20 & -0.46 & 0.26 \\
\hline SECT.E & -0.21 & -0.02 & -0.04 & 0.16 & 0.04 & 0.02 & 0.10 & 0.25 & 0.11 \\
\hline Country & 0.10 & -0.16 & -0.04 & -0.22 & -0.14 & -0.18 & -0.07 & -0.64 & 0.21 \\
\hline \multicolumn{10}{|c|}{ Pearson correlation coefficients between variables } \\
\hline Variable & $\begin{array}{c}\text { Year. } \\
06\end{array}$ & $\begin{array}{c}\text { Year. } \\
07\end{array}$ & $\begin{array}{c}\text { Year. } \\
08\end{array}$ & $\begin{array}{c}\text { SECT. } \\
\text { A }\end{array}$ & $\begin{array}{c}\text { SECT. } \\
\text { B }\end{array}$ & $\begin{array}{c}\text { SECT. } \\
\text { C }\end{array}$ & $\begin{array}{c}\text { SECT. } \\
\text { D }\end{array}$ & $\begin{array}{c}\text { SECT. } \\
\text { E }\end{array}$ & Country \\
\hline YEAR.06 & 1.00 & & & & & & & & \\
\hline YEAR.07 & -0.44 & 1.00 & & & & & & & \\
\hline YEAR.08 & -0.52 & -0.54 & 1.00 & & & & & & \\
\hline SECT.A & 0.01 & 0.00 & -0.01 & 1.00 & & & & & \\
\hline SECT.B & 0.02 & -0.09 & 0.07 & -0.30 & 1.00 & & & & \\
\hline SECT.C & 0.05 & -0.03 & -0.02 & -0.20 & -0.17 & 1.00 & & & \\
\hline SECT.D & -0.01 & 0.02 & 0.00 & -0.37 & -0.31 & -0.21 & 1.00 & & \\
\hline SECT.E & -0.06 & 0.09 & -0.03 & -0.26 & -0.21 & -0.14 & -0.27 & 1.00 & \\
\hline Country & 0.05 & -0.05 & 0.00 & -0.15 & 0.05 & 0.13 & 0.10 & -0.11 & 1.00 \\
\hline
\end{tabular}

Table 7. Univariate Correlations - Italian and British Companies

Two variables related to goodwill impairment are correlated with the disclosure score (with Pearson coefficients equal to 0.03 and 0.10 respectively for IMP/AST and IMP/EQT). Both profitability ratios are positively correlated with the disclosure score (with coefficients equal to 0.12 and 0.15 respectively for ROE and AVG.ROE).

We also note positive coefficients related to firm size and to the dummy variable referred to the year 2008. The results referred to the variables concerning the quality of corporate governance are controversial, as the first correlation is positive (A.C.MEET equal to 0.07), whilst the second is negative (A.C.IND.DIR. equal to -0.14). 
Table 8 provides Pearson correlation coefficients between variables for the entire Italian sample.

\begin{tabular}{|c|c|c|c|c|c|c|c|c|c|}
\hline \multicolumn{10}{|c|}{ Pearson Correlation Coefficients Between Variables } \\
\hline Variable & Disc & $\begin{array}{c}\text { Imp / } \\
\text { Ast }\end{array}$ & $\begin{array}{c}\text { Imp / } \\
\text { Eqt }\end{array}$ & $\begin{array}{c}\text { Imp / } \\
\text { Gdw }\end{array}$ & Roe & $\begin{array}{l}\text { Avg. } \\
\text { Roe }\end{array}$ & $\begin{array}{l}\text { A.C. } \\
\text { Meet. }\end{array}$ & $\begin{array}{l}\text { A.C.Ind } \\
\text {.Dir. }\end{array}$ & Size \\
\hline DISC & 1.00 & & & & & & & & \\
\hline IMP / AST & 0.15 & 1.00 & & & & & & & \\
\hline IMP / EQT & 0.14 & 0.99 & 1.00 & & & & & & \\
\hline IMP / GDW & 0.14 & 0.91 & 0.88 & 1.00 & & & & & \\
\hline ROE & 0.29 & 0.09 & 0.07 & 0.08 & 1.00 & & & & \\
\hline AVG.ROE & 0.23 & 0.04 & 0.04 & 0.06 & 0.31 & 1.00 & & & \\
\hline A.C.MEET. & -0.02 & 0.22 & 0.21 & 0.32 & -0.09 & 0.00 & 1.00 & & \\
\hline A.C.IND.DIR. & -0.27 & 0.20 & 0.20 & 0.19 & -0.15 & -0.03 & 0.39 & 1.00 & \\
\hline SIZE & 0.38 & -0.12 & -0.12 & -0.13 & 0.12 & -0.02 & 0.06 & -0.48 & 1.00 \\
\hline YEAR.06 & -0.08 & 0.16 & 0.18 & 0.11 & -0.01 & -0.19 & -0.17 & -0.04 & 0.02 \\
\hline YEAR.07 & -0.16 & -0.11 & -0.09 & -0.18 & 0.18 & 0.08 & -0.08 & 0.05 & 0.00 \\
\hline YEAR.08 & 0.23 & -0.04 & -0.08 & 0.06 & -0.15 & 0.11 & 0.24 & -0.01 & -0.02 \\
\hline SECT.A & -0.16 & 0.30 & 0.28 & 0.24 & 0.01 & 0.07 & 0.20 & 0.39 & -0.52 \\
\hline SECT.B & 0.12 & -0.09 & -0.08 & -0.07 & 0.04 & 0.09 & -0.20 & 0.29 & -0.37 \\
\hline SECT.C & 0.29 & -0.07 & -0.06 & -0.11 & -0.17 & -0.33 & 0.08 & -0.07 & 0.36 \\
\hline SECT.D & 0.15 & -0.10 & -0.10 & -0.03 & 0.26 & 0.11 & -0.20 & -0.67 & 0.53 \\
\hline SECT.E & -0.49 & -0.05 & -0.05 & -0.04 & -0.27 & -0.01 & 0.21 & 0.19 & -0.02 \\
\hline \multicolumn{10}{|c|}{ Pearson Correlation Coefficients Between Variables } \\
\hline \multicolumn{2}{|c|}{ Variable } & $\begin{array}{c}\text { Year. } \\
06\end{array}$ & $\begin{array}{c}\text { Year. } \\
07\end{array}$ & $\begin{array}{c}\text { Year. } \\
08\end{array}$ & SECT.A & SECT.B & SECT.C & SECT.D & SECT.E \\
\hline \multicolumn{2}{|l|}{ YEAR.06 } & 1.00 & & & & & & & \\
\hline \multicolumn{2}{|l|}{ YEAR.07 } & -0.44 & 1.00 & & & & & & \\
\hline \multicolumn{2}{|l|}{ YEAR.08 } & -0.55 & -0.51 & 1.00 & & & & & \\
\hline \multicolumn{2}{|l|}{ SECT.A } & -0.08 & 0.05 & 0.03 & 1.00 & & & & \\
\hline \multicolumn{2}{|l|}{ SECT.B } & -0.02 & -0.07 & 0.08 & -0.27 & 1.00 & & & \\
\hline \multicolumn{2}{|l|}{ SECT.C } & 0.04 & -0.03 & -0.01 & -0.20 & -0.21 & 1.00 & & \\
\hline \multicolumn{2}{|l|}{ SECT.D } & 0.07 & -0.04 & -0.03 & -0.35 & -0.37 & -0.27 & 1.00 & \\
\hline \multicolumn{2}{|l|}{ SECT.E } & -0.03 & 0.11 & -0.08 & -0.19 & -0.20 & -0.15 & -0.25 & 1.00 \\
\hline
\end{tabular}

Table 8. Univariate Correlations - Italian Companies

Of particular interest, all the three variables related to goodwill impairment exhibit a positive correlation with the level of disclosure (equal to $0.15,0.14$ and 0.14 respectively for IMP/AST, IMP/EQT and IMP/GDW). As predicted, this provides a preliminary indication on a univariate basis that the magnitude of goodwill write-offs is positively associated with the degree of firm disclosure on impairment test.

Moreover, both return on equity ratios are positively correlated with the disclosure score (with Pearson coefficients equal to 0.29 and 0.23 respectively for ROE and AVG.ROE). Also this finding is consistent with our hypothesis.

The level of disclosure is also positively correlated with our proxy for firm size, suggesting that the costs of disclosure decrease for larger firms, and with the dummy variable referred to the year 2008, confirming the predicted improvement in corporate disclosure before the first years of IAS 36 application.

Surprisingly, both the corporate governance related variables exhibit negative coefficients. 
Pearson correlation coefficients between variables for the whole British sample are shown in Table 9.

\begin{tabular}{|c|c|c|c|c|c|c|c|c|c|}
\hline \multicolumn{10}{|c|}{ Pearson Correlation Coefficients Between Variables } \\
\hline Variable & Disc & $\begin{array}{c}\text { Imp / } \\
\text { Ast }\end{array}$ & $\begin{array}{c}\text { Imp / } \\
\text { Eqt }\end{array}$ & $\begin{array}{c}\text { Imp / } \\
\text { Gdw }\end{array}$ & Roe & $\begin{array}{l}\text { Avg. } \\
\text { Roe }\end{array}$ & $\begin{array}{l}\text { A.C. } \\
\text { Meet. }\end{array}$ & $\begin{array}{l}\text { A.C.Ind. } \\
\text { Dir. }\end{array}$ & Size \\
\hline DISC & 1.00 & & & & & & & & \\
\hline IMP / AST & 0.01 & 1.00 & & & & & & & \\
\hline IMP / EQT & 0.04 & 0.94 & 1.00 & & & & & & \\
\hline IMP / GDW & 0.01 & 0.66 & 0.68 & 1.00 & & & & & \\
\hline ROE & -0.07 & -0.20 & -0.26 & -0.26 & 1.00 & & & & \\
\hline AVG.ROE & 0.01 & 0.05 & 0.20 & 0.03 & 0.04 & 1.00 & & & \\
\hline A.C.MEET. & 0.36 & 0.22 & 0.15 & 0.02 & -0.09 & -0.22 & 1.00 & & \\
\hline A.C.IND.DIR. & 0.12 & 0.15 & 0.07 & 0.27 & -0.08 & -0.18 & 0.03 & 1.00 & \\
\hline SIZE & 0.30 & -0.23 & -0.25 & -0.10 & 0.24 & -0.18 & 0.55 & 0.07 & 1.00 \\
\hline YEAR.06 & -0.17 & 0.02 & -0.04 & -0.14 & 0.17 & 0.07 & -0.04 & 0.00 & 0.01 \\
\hline YEAR.07 & -0.01 & -0.19 & -0.21 & -0.22 & 0.26 & -0.03 & -0.07 & -0.09 & 0.08 \\
\hline YEAR.08 & 0.17 & 0.16 & 0.24 & 0.33 & -0.40 & -0.03 & 0.11 & 0.09 & -0.08 \\
\hline SECT.A & 0.02 & 0.30 & 0.30 & 0.09 & -0.27 & 0.22 & 0.15 & 0.09 & -0.27 \\
\hline SECT.B & 0.33 & -0.15 & -0.15 & -0.16 & 0.01 & 0.04 & 0.10 & -0.25 & -0.09 \\
\hline SECT.C & 0.30 & -0.07 & -0.07 & -0.07 & -0.01 & -0.07 & 0.08 & 0.26 & 0.38 \\
\hline SECT.D & -0.56 & -0.12 & -0.11 & -0.10 & 0.00 & -0.26 & -0.19 & -0.30 & -0.08 \\
\hline SECT.E & 0.08 & -0.04 & -0.05 & 0.19 & 0.32 & 0.02 & -0.11 & 0.29 & 0.27 \\
\hline \multicolumn{10}{|c|}{ Pearson Correlation Coefficients Between Variables } \\
\hline \multicolumn{2}{|c|}{ Variable } & $\begin{array}{c}\text { Year. } \\
06\end{array}$ & $\begin{array}{c}\text { Year. } \\
07\end{array}$ & $\begin{array}{c}\text { Year. } \\
08\end{array}$ & SECT.A & SECT.B & SECT.C & SECT. D & SECT. E \\
\hline \multicolumn{2}{|l|}{ YEAR.06 } & 1.00 & & & & & & & \\
\hline \multicolumn{2}{|l|}{ YEAR.07 } & -0.43 & 1.00 & & & & & & \\
\hline \multicolumn{2}{|l|}{ YEAR.08 } & -0.49 & -0.57 & 1.00 & & & & & \\
\hline \multicolumn{2}{|l|}{ SECT.A } & 0.12 & -0.06 & -0.06 & 1.00 & & & & \\
\hline \multicolumn{2}{|l|}{ SECT.B } & 0.06 & -0.11 & 0.05 & -0.33 & 1.00 & & & \\
\hline \multicolumn{2}{|l|}{ SECT.C } & 0.03 & 0.00 & -0.03 & -0.18 & -0.12 & 1.00 & & \\
\hline \multicolumn{2}{|l|}{ SECT.D } & -0.13 & 0.10 & 0.03 & -0.39 & -0.26 & -0.14 & 1.00 & \\
\hline \multicolumn{2}{|l|}{ SECT.E } & -0.08 & 0.07 & 0.01 & -0.35 & -0.23 & -0.12 & -0.27 & 1.00 \\
\hline
\end{tabular}

Table 9. Univariate Correlations - British Companies

Contrary to the Italian findings, the coefficients report no significant relation between goodwill impairment ratios and the level of disclosure (with Pearson coefficients equal to $0.01,0.04$ and 0.01 respectively for IMP/AST, IMP/EQT and IMP/GDW).

Furthermore, both return on equity ratios are not significantly correlated with the disclosure score (with Pearson coefficient equal to -0.07 for ROE and 0.01 for AVG.ROE).

However, similarly to the Italian results, the level of disclosure is positively correlated with firm size and with the dummy variable referred to the year 2008.

The two corporate governance variables show positive coefficients, in contrast with the Italian cases.

As discussed earlier, we conducted regression tests by including only one proxy at a time for goodwill impairment and profitability, also in order to mitigate possible effects of multicollinearity (Chen \& Jaggi, 2000). In Tables 7, 8 and 9 it has been observed, as a result, that the highest simple correlation between the independent variables considered in each 
regression model does not exceed 0.70 , suggesting that multicollinearity is unlikely to pose a serious problem in the interpretation of the results of the multivariate analysis (Hossain \& Hammami, 2009).

\section{Regression Results}

Table 10 reports on multivariate tests of the determinants of corporate disclosure in the Italian and British sample.

\begin{tabular}{|c|c|c|c|c|c|c|c|c|c|}
\hline \multicolumn{10}{|c|}{ Dependent Variable: Disc } \\
\hline \multirow[b]{2}{*}{ Variable } & \multicolumn{3}{|c|}{ Model 1} & \multicolumn{3}{|c|}{ Model 2} & \multicolumn{3}{|c|}{ Model 3} \\
\hline & Coefficient & $\begin{array}{c}\mathrm{t}- \\
\text { statistic }\end{array}$ & $\begin{array}{c}\text { p- } \\
\text { value }\end{array}$ & Coefficient & $\begin{array}{c}\mathbf{t}- \\
\text { statistic }\end{array}$ & $\begin{array}{c}\text { p- } \\
\text { value }\end{array}$ & Coefficient & $\begin{array}{c}\mathbf{t}- \\
\text { statistic }\end{array}$ & $\begin{array}{c}\text { p- } \\
\text { value }\end{array}$ \\
\hline INTERCEPT & $* *-5.336$ & -2.138 & 0.035 & $* *-5.315$ & -2.168 & 0.033 & $*-4.956$ & -1.979 & 0.051 \\
\hline IMP / AST & $* 16.805$ & 1.746 & 0.084 & & & & & & \\
\hline IMP / EQT & & & & $* * 7.037$ & 2.458 & 0.016 & & & \\
\hline$I M P / G D W$ & & & & & & & 1.672 & 1.117 & 0.267 \\
\hline ROE & $* * 3.892$ & 1.995 & 0.049 & $* 3.685$ & 1.916 & 0.058 & $* * 4.058$ & 2.055 & 0.043 \\
\hline \multicolumn{10}{|l|}{ AVG.ROE } \\
\hline A.C.MEET. & -0.086 & -0.714 & 0.477 & -0.110 & -0.915 & 0.362 & -0.050 & -0.413 & 0.680 \\
\hline A.C.IND.DIR. & -2.966 & -1.314 & 0.192 & -3.111 & -1.397 & 0.166 & -3.192 & -1.386 & 0.169 \\
\hline SIZE & $* * * 0.729$ & 4.517 & 0.000 & $* * * 0.741$ & 4.662 & 0.000 & $* * * 0.697$ & 4.312 & 0.000 \\
\hline YEAR.07 & 0.430 & 0.829 & 0.409 & 0.500 & 0.975 & 0.332 & 0.340 & 0.654 & 0.515 \\
\hline YEAR.08 & $* * * 1.541$ & 3.070 & 0.003 & $* * * 1.617$ & 3.261 & 0.002 & $* * * 1.427$ & 2.781 & 0.007 \\
\hline SECT.A & $* * * 1.934$ & 2.785 & 0.006 & $* * * 1.868$ & 2.728 & 0.008 & $* * * 2.124$ & 3.042 & 0.003 \\
\hline SECT.B & $* * * 3.013$ & 4.182 & 0.000 & $* * * 3.006$ & 4.242 & 0.000 & $* * * 3.062$ & 4.160 & 0.000 \\
\hline SECT.C & $* * * 2.620$ & 3.072 & 0.003 & $* * * 2.608$ & 3.102 & 0.003 & $* * * 2.721$ & 3.142 & 0.002 \\
\hline SECT.D & -0.118 & -0.164 & 0.870 & -0.156 & -0.220 & 0.826 & -0.046 & -0.064 & 0.949 \\
\hline Country & -0.399 & -0.719 & 0.474 & -0.532 & -0.971 & 0.334 & -0.414 & -0.739 & 0.462 \\
\hline$n$ & & \multicolumn{3}{|l|}{110} & \multicolumn{3}{|l|}{110} \\
\hline Adjusted $\mathbf{R}^{2}$ & 0.352 & & & 0.371 & & & 0.340 & & \\
\hline \multirow{2}{*}{ Variable } & \multicolumn{3}{|c|}{ Model 4} & \multicolumn{3}{|c|}{ Model 5} & \multicolumn{3}{|c|}{ Model 6} \\
\hline & Coefficient & $\begin{array}{c}\mathbf{t}- \\
\text { statistic }\end{array}$ & $\begin{array}{c}\mathrm{p}- \\
\text { value }\end{array}$ & Coefficient & $\begin{array}{c}\mathbf{t}- \\
\text { statistic }\end{array}$ & $\begin{array}{c}\text { p- } \\
\text { value }\end{array}$ & Coefficient & $\begin{array}{c}\mathbf{t}- \\
\text { statistic }\end{array}$ & $\begin{array}{c}\text { p- } \\
\text { value }\end{array}$ \\
\hline INTERCEPT & $* *-5.388$ & -2.176 & 0.032 & $* *-5.371$ & -2.207 & 0.030 & $* *-5.022$ & -2.019 & 0.046 \\
\hline IMP / AST & $* * 15.985$ & 1.671 & 0.098 & & & & & & \\
\hline IMP / EQT & & & & $* * 6.797$ & 2.385 & 0.019 & & & \\
\hline$I M P / G D W$ & & & & & & & 1.390 & 0.937 & 0.351 \\
\hline \multicolumn{10}{|l|}{ ROE } \\
\hline AVG.ROE & $* * 0.896$ & 2.317 & 0.023 & $* * 0.851$ & 2.228 & 0.028 & $* * 0.915$ & 2.343 & 0.021 \\
\hline A.C.MEET. & -0.083 & -0.688 & 0.493 & -0.106 & -0.887 & 0.377 & -0.049 & -0.411 & 0.682 \\
\hline A.C.IND.DIR. & -2.703 & -1.203 & 0.232 & -2.858 & -1.290 & 0.200 & -2.867 & -1.251 & 0.214 \\
\hline SIZE & $* * * 0.752$ & 4.745 & 0.000 & $* * * 0.762$ & 4.888 & 0.000 & $* * * 0.722$ & 4.549 & 0.000 \\
\hline YEAR.07 & 0.397 & 0.768 & 0.445 & 0.467 & 0.915 & 0.363 & 0.307 & 0.593 & 0.554 \\
\hline YEAR.08 & $* * 1.224$ & 2.475 & 0.015 & $* * * 1.314$ & 2.684 & 0.009 & $* * 1.118$ & 2.205 & 0.030 \\
\hline SECT.A & $* * 1.798$ & 2.599 & 0.011 & $* * 1.740$ & 2.550 & 0.012 & $* * * 1.969$ & 2.828 & 0.006 \\
\hline SECT.B & $* * * 3.019$ & 4.223 & 0.000 & $* * * 3.014$ & 4.283 & 0.000 & $* * * 3.051$ & 4.170 & 0.000 \\
\hline SECT.C & $* * * 2.856$ & 3.308 & 0.001 & $* * * 2.832$ & 3.328 & 0.001 & $* * * 2.940$ & 3.359 & 0.001 \\
\hline SECT.D & -0.001 & -0.001 & 0.999 & -0.044 & -0.063 & 0.950 & 0.063 & 0.088 & 0.930 \\
\hline Country & -0.367 & -0.664 & 0.508 & -0.496 & -0.909 & 0.365 & -0.386 & -0.693 & 0.490 \\
\hline$n$ & \multicolumn{3}{|l|}{110} & \multicolumn{3}{|l|}{110} & \multicolumn{3}{|l|}{110} \\
\hline Adjusted $\mathbf{R}^{2}$ & \multicolumn{3}{|l|}{0.361} & \multicolumn{3}{|l|}{0.379} & \multicolumn{3}{|l|}{0.349} \\
\hline
\end{tabular}

Table 10. Multivariate Linear Regressions - Italian and British Companies 
The analysis of the residuals, founded on the exam of histograms and normal probability plots, confirms in all the models that the Ordinary Least Squares regressions are the most suitable techniques for testing our hypotheses. In addition, we calculated the Variance Inflation Factor (VIF) score for each independent variable, in order to evaluate whether multicollinearity may be a cause of concern. VIF scores higher than 10 are commonly taken as an indication of multicollinearity: in our cases, the highest VIF obtained is only 2.715.

The specification for the six multivariate regressions (Model 1 to 6 ) is provided in Section 4 .

Model 1 and Model 4 scale goodwill impairment by total assets; the performance indicators are, respectively, ROE and AVG.ROE.

The multiple linear regressions show that the association between goodwill impairment and the dependent variable DISC is significant at the 0.10 level in the predicted sense; the disclosure level is significantly and positively associated at the 0.05 level with the alternative profitability ratios. The model adjusted $\mathrm{R} 2$ are equal to about 0.35 .

Model 2 and Model 5 scale goodwill impairment by total assets. As expected, the multiple linear regressions shows that the dependent variable DISC is significantly and positively associated (at the 0.05 level) with goodwill impairment, with the model adjusted R2 equal to about 0.37 . The positive association between DISC and performance indicators is significant respectively at the $90 \%$ and $95 \%$ confidence level.

Finally, when in Models 3 and 6 goodwill impairment is scaled by goodwill, the association between goodwill write-offs and disclosure is not significant, whilst the alternative profitability ratios are significantly associated with disclosure score in the predicted sense. The model adjusted $\mathrm{R} 2$ is equal to about 0.34 .

In summary, addressing the first research question of the positive association between goodwill write-offs and disclosure (see $\mathrm{H} 1$ ), the findings are significant in the predicted sense in four models.

Looking at the research question of the positive association between earnings performance and corporate disclosure (see $\mathrm{H} 2$ ), in all six models ROE and AVG.ROE coefficients are statistically significant in the predicted direction.

In all six regressions the model adjusted R2 is higher than 0.3 .

Furthermore, all six models show that the level of disclosure is highly significantly associated in the prediction sense with firm size and with the dummy variable referred to the year 2008, confirming the findings of the univariate tests. As predicted, also the coefficients of the dummy 
variables for each sector, only except for sector D, are highly significantly associated with corporate disclosure.

Other similar regression models, not presented in Table 10, show negative but insignificant coefficients associated with dummy variable YEAR.2006, and positive but insignificant coefficients on dummy variable SECT.E.

In all six models the coefficients referred to the quality of corporate governance are negative but statistically insignificant. Similarly, the dummy variable for the country exhibit coefficients always insignificant, showing that firm nationality does not influence the general level of disclosure about goodwill impairment test.

Next, we examine separately the two samples of Italian and British firms, in order to test if the results have been affected by inclusion of Italian company, having regard to our third research question (see H3).

Table 11 reports on multivariate tests of the determinants of corporate disclosure in the Italian sample.

In order to test whether relevant multicollinearity is affecting the results, we performed the Variance Inflation Factor for the Italian cases: the maximum VIF is equal to only 4.394, so confirming that multicollinearity among the predictor variables is not a problem. Moreover, the analysis of the residuals through the Durbin-Watson test does not provide evidence of autocorrelation.

Model 1a scales goodwill impairment by total assets; the performance indicator is ROE.

As expected, the multiple linear regression shows that the dependent variable DISC is significantly and positively associated (at the 0.05 level) with goodwill impairment and (at the 0.10 level) with return on equity ratio. The model adjusted R2 is equal to 0.47 .

Similarly, in Model 4a, when goodwill impairment is scaled by total assets again and the performance indicator is AVG.ROE, the level of disclosure is significantly associated in the predicted direction with goodwill impairment (at the 0.05 level) as well as return on equity ratio, with the model adjusted $\mathrm{R} 2$ equal to 0.50 .

In the Italian sample, addressing the first research question of the positive association between goodwill write-offs and disclosure (see $\mathrm{H} 1$ ), this finding of the value-relevance of goodwill impairment is confirmed when alternative scalars are used. Actually, as can be seen from Table 11, when impairment goodwill is scaled by equity (Model 2a and Model 5a), the magnitude of goodwill write-offs is positively associated with corporate disclosure at the $95 \%$ 
confidence level. Finally, in Models $3 a$ and $6 a$, the level of disclosure is positively associated (respectively at the $90 \%$ and $95 \%$ confidence level) with goodwill impairment scaled by goodwill.

\begin{tabular}{|c|c|c|c|c|c|c|c|c|c|}
\hline \multicolumn{10}{|c|}{ Dependent variable: DISC } \\
\hline \multirow[b]{2}{*}{ Variable } & \multicolumn{3}{|c|}{ Model 1a } & \multicolumn{3}{|c|}{ Model 2a } & \multicolumn{3}{|c|}{ Model 3a } \\
\hline & Coefficient & $\begin{array}{c}\mathbf{t}- \\
\text { statistic }\end{array}$ & $\begin{array}{c}\text { p- } \\
\text { value }\end{array}$ & Coefficient & $\begin{array}{c}\mathrm{t}- \\
\text { statistic }\end{array}$ & $\begin{array}{c}\text { p- } \\
\text { value }\end{array}$ & Coefficient & $\begin{array}{c}\mathrm{t}- \\
\text { statistic }\end{array}$ & $\begin{array}{c}\text { p- } \\
\text { value }\end{array}$ \\
\hline INTERCEPT & $*-7.270$ & -1.968 & 0.055 & $*-7.305$ & -1.972 & 0.054 & $* *-7.876$ & -2.117 & 0.040 \\
\hline IMP / AST & $* * 48.907$ & 2.127 & 0.039 & & & & & & \\
\hline IMP / EQT & & & & $* * 6.510$ & 2.055 & 0.045 & & & \\
\hline$I M P$ / GDW & & & & & & & $* 25.334$ & 1.986 & 0.053 \\
\hline ROE & $* 4.233$ & 1.714 & 0.093 & $* 4.393$ & 1.779 & 0.082 & $4.227^{*}$ & 1.701 & 0.096 \\
\hline \multicolumn{10}{|l|}{ AVG.ROE } \\
\hline A.C.MEET. & 0.010 & 0.072 & 0.943 & 0.010 & 0.071 & 0.944 & -0.022 & -0.155 & 0.878 \\
\hline A.C.IND.DIR. & -4.600 & -1.332 & 0.189 & -4.647 & -1.341 & 0.186 & -4.610 & -1.327 & 0.191 \\
\hline SIZE & $* * * 0.766$ & 2.836 & 0.007 & $* * * 0.771$ & 2.848 & 0.007 & $* * * 0.819$ & 3.006 & 0.004 \\
\hline YEAR.07 & 0.054 & 0.081 & 0.936 & 0.033 & 0.050 & 0.960 & 0.047 & 0.069 & 0.945 \\
\hline YEAR.08 & $* 1.202$ & 1.887 & 0.065 & $* 1.241$ & 1.931 & 0.060 & $* 1.112$ & 1.752 & 0.086 \\
\hline SECT.A & $* * * 3.046$ & 2.867 & 0.006 & $* * * 3.068$ & 2.882 & 0.006 & $* * * 3.231$ & 3.055 & 0.004 \\
\hline SECT.B & $* * * 4.327$ & 4.198 & 0.000 & $* * * 4.292$ & 4.152 & 0.000 & $* * * 4.325$ & 4.173 & 0.000 \\
\hline SECT.C & $* * * 3.643$ & 3.280 & 0.002 & $* * * 3.596$ & 3.228 & 0.002 & $* * * 3.617$ & 3.238 & 0.002 \\
\hline SECT.D & 1.682 & 1.513 & 0.137 & 1.636 & 1.466 & 0.149 & 1.519 & 1.353 & 0.183 \\
\hline$n$ & \multicolumn{3}{|l|}{59} & \multicolumn{3}{|l|}{59} & \multicolumn{3}{|l|}{59} \\
\hline Adjusted $\mathbf{R}^{2}$ & \multirow{2}{*}{\multicolumn{3}{|c|}{0.466}} & \multicolumn{3}{|l|}{0.463} & \multicolumn{3}{|l|}{0.460} \\
\hline \multirow[b]{2}{*}{ Variable } & & & & \multicolumn{3}{|c|}{ Model 5a } & \multicolumn{3}{|c|}{ Model 6a } \\
\hline & Coefficient & $\begin{array}{c}\mathrm{t}- \\
\text { statistic }\end{array}$ & $\begin{array}{c}\text { p- } \\
\text { value }\end{array}$ & coefficient & $\begin{array}{c}\mathrm{t}- \\
\text { statistic }\end{array}$ & $\begin{array}{c}\text { p- } \\
\text { value }\end{array}$ & Coefficient & $\begin{array}{c}\mathrm{t}- \\
\text { statistic }\end{array}$ & $\begin{array}{c}\text { p- } \\
\text { value }\end{array}$ \\
\hline INTERCEPT & $*-6.837$ & -1.915 & 0.062 & $*-6.917$ & -1.927 & 0.060 & $* *-7.459$ & -2.075 & 0.044 \\
\hline IMP / AST & $* * 50.008$ & 2.259 & 0.029 & & & & & & \\
\hline IMP / EQT & & & & $* * 6.509$ & 2.123 & 0.039 & & & \\
\hline IMP / GDW & & & & & & & $* * 25.922$ & 2.112 & 0.040 \\
\hline \multicolumn{10}{|l|}{ ROE } \\
\hline AVG.ROE & $* * 0.969$ & 2.539 & 0.014 & $* * 0.970$ & 2.526 & 0.015 & $* * 0.967$ & 2.516 & 0.015 \\
\hline A.C.MEET. & 0.017 & 0.129 & 0.898 & 0.018 & 0.138 & 0.891 & -0.015 & -0.114 & 0.910 \\
\hline A.C.IND.DIR. & -4.426 & -1.325 & 0.191 & -4.477 & -1.332 & 0.189 & -4.437 & -1.320 & 0.193 \\
\hline SIZE & $* * * 0.732$ & 2.804 & 0.007 & $* * * 0.741$ & 2.820 & 0.007 & $* * * 0.787$ & 2.986 & 0.004 \\
\hline YEAR.07 & -0.007 & -0.011 & 0.991 & -0.028 & -0.043 & 0.966 & -0.014 & -0.022 & 0.982 \\
\hline YEAR.08 & 0.851 & 1.370 & 0.177 & 0.880 & 1.399 & 0.168 & 0.760 & 1.228 & 0.226 \\
\hline SECT.A & $* * * 3.284$ & 3.298 & 0.002 & $* * * 3.336$ & 3.339 & 0.002 & $* * * 3.473$ & 3.510 & 0.001 \\
\hline SECT.B & $* * * 4.618$ & 4.840 & 0.000 & $* * * 4.606$ & 4.799 & 0.000 & $* * * 4.616$ & 4.808 & 0.000 \\
\hline SECT.C & $* * * 4.441$ & 3.999 & 0.000 & $* * * 4.397$ & 3.935 & 0.000 & $* * * 4.412$ & 3.947 & 0.000 \\
\hline SECT.D & $* * 2.200$ & 2.103 & 0.041 & $* * 2.174$ & 2.064 & 0.045 & $* 2.032$ & 1.917 & 0.061 \\
\hline$n$ & \multicolumn{3}{|l|}{59} & \multicolumn{3}{|l|}{59} & \multicolumn{3}{|l|}{59} \\
\hline Adjusted $\mathbf{R}^{2}$ & \multicolumn{3}{|l|}{0.501} & \multicolumn{3}{|l|}{0.495} & \multicolumn{3}{|l|}{0.495} \\
\hline
\end{tabular}

Table 11. Multivariate Linear Regressions - Italian Companies

With reference to the second research question, concerning the positive association between earnings performance and corporate disclosure (see $\mathrm{H} 2$ ), in all six models ROE and AVG.ROE coefficients are statistically significant in the predicted direction, at the 90\% (Models $1 \mathrm{a}, 2 \mathrm{a}$ and $3 a$ ) or $95 \%$ (Models $4 a, 5 a$ and $6 a$ ) confidence level.

In all six regressions the model adjusted $\mathrm{R} 2$ is higher than 0.45 . 
It should be noted that the similarity of the coefficients on both goodwill impairment and performance indicators give confidence in the robustness of the results across the different scalars.

Furthermore, all six models show that the level of disclosure is highly significantly associated in the prediction sense with firm size and with the dummy variables for each sector (only except for sector D).

Other similar regression models, not presented in Table 11, show negative but insignificant coefficients associated with dummy variable YEAR.2006, and negative coefficients on dummy variable SECT.E, statistically significant at the 0.05 level.

The coefficients related to the quality of corporate governance are not significant, while the positive coefficient referring to the dummy variable for the year 2008 is significant at the $90 \%$ level in the first three models.

Table 12 reports on multivariate tests of the determinants of corporate disclosure in the British sample.

Also in the British cases, the VIF scores calculated for each independent variable confirm that multicollinearity does not represent a problem, as the largest VIF score is equal to only 3.444 . Similarly to the Italian results, the analysis of the residuals through the Durbin-Watson test does not provide evidence of autocorrelation.

As can be seen, the multiple linear regressions shows that in all six models (Model $1 \mathrm{~b}$ to Model $6 b)$ the coefficients on goodwill impairment are statistically insignificant, with each model adjusted R2 around 0.42 .

Furthermore, no relation is found between return on equity ratios and disclosure score: in all six models the coefficients are negative but not statistically significant.

However, all six regressions show that the level of disclosure is significantly associated in the prediction sense with the dummy variable for the year 2008, while the positive coefficients related to firm size are not significant. Looking at the dummy variables referred to firm sector, only SECT.D is significantly associated to score disclosure.

Other similar regression models, not presented in Table 12, show negative coefficients on dummy variable YEAR.2006, statistically significant at the 0.10 level, and positive coefficients associated with dummy variable SECT.E, significant at the 0.01 level. 


\begin{tabular}{|c|c|c|c|c|c|c|c|c|c|}
\hline \multicolumn{10}{|c|}{ Dependent variable: DISC } \\
\hline \multirow[b]{2}{*}{ Variable } & \multicolumn{3}{|c|}{ Model 1b } & \multicolumn{3}{|c|}{ Model 2b } & \multicolumn{3}{|c|}{ Model 3b } \\
\hline & Coefficient & $\begin{array}{c}\mathrm{t}- \\
\text { statistic }\end{array}$ & $\begin{array}{c}\text { p- } \\
\text { value }\end{array}$ & Coefficient & $\begin{array}{c}\mathbf{t}- \\
\text { statistic }\end{array}$ & $\begin{array}{c}\text { p- } \\
\text { value }\end{array}$ & Coefficient & $\begin{array}{c}\mathrm{t}- \\
\text { statistic }\end{array}$ & $\begin{array}{c}\text { p- } \\
\text { value }\end{array}$ \\
\hline INTERCEPT & 1.403 & 0.374 & 0.710 & 1.017 & 0.270 & 0.788 & 1.461 & 0.410 & 0.684 \\
\hline IMP / AST & -0.206 & -0.018 & 0.985 & & & & & & \\
\hline IMP / EQT & & & & 1.708 & 0.290 & 0.773 & & & \\
\hline$I M P / G D W$ & & & & & & & -0.359 & -0.239 & 0.812 \\
\hline ROE & -1.210 & -0.384 & 0.703 & -1.154 & -0.366 & 0.716 & -1.336 & -0.418 & 0.678 \\
\hline \multicolumn{10}{|l|}{ AVG.ROE } \\
\hline A.C.MEET. & 0.311 & 0.784 & 0.438 & 0.270 & 0.715 & 0.479 & 0.314 & 0.882 & 0.383 \\
\hline A.C.IND.DIR. & -1.304 & -0.400 & 0.691 & -1.223 & -0.374 & 0.710 & -1.184 & -0.359 & 0.721 \\
\hline SIZE & 0.195 & 0.674 & 0.504 & 0.228 & 0.812 & 0.422 & 0.191 & 0.728 & 0.471 \\
\hline YEAR.07 & 1.219 & 1.683 & 0.100 & $* 1.240$ & 1.722 & 0.093 & $1.213^{*}$ & 1.690 & 0.099 \\
\hline YEAR.08 & $* 1.464$ & 1.940 & 0.060 & $* 1.447$ & 1.914 & 0.063 & $1.495^{*}$ & 1.955 & 0.058 \\
\hline SECT.A & -0.168 & -0.161 & 0.873 & -0.134 & -0.129 & 0.898 & -0.206 & -0.197 & 0.845 \\
\hline SECT.B & 1.400 & 1.197 & 0.239 & 1.504 & 1.288 & 0.205 & 1.343 & 1.168 & 0.250 \\
\hline SECT.C & 2.232 & 1.634 & 0.110 & 2.218 & 1.626 & 0.112 & 2.177 & 1.573 & 0.124 \\
\hline SECT.D & $* * *-2.980$ & -2.974 & 0.005 & $* * *-2.923$ & -2.909 & 0.006 & $* * *-3.022$ & -3.006 & 0.005 \\
\hline$n$ & \multicolumn{3}{|l|}{51} & \multicolumn{3}{|l|}{51} & \multicolumn{3}{|l|}{51} \\
\hline Adjusted $\mathbf{R}^{2}$ & \multicolumn{3}{|l|}{0.418} & \multicolumn{3}{|l|}{0.419} & \multicolumn{3}{|l|}{0.419} \\
\hline \multirow[b]{2}{*}{ Variable } & \multicolumn{3}{|c|}{ Model 4b } & \multicolumn{3}{|c|}{ Model 5b } & \multicolumn{3}{|c|}{ Model 6b } \\
\hline & Coefficient & $\begin{array}{c}\mathrm{t}- \\
\text { statistic }\end{array}$ & $\begin{array}{c}\text { p- } \\
\text { value }\end{array}$ & Coefficient & $\begin{array}{c}\mathbf{t}- \\
\text { statistic }\end{array}$ & $\begin{array}{c}\text { p- } \\
\text { value }\end{array}$ & Coefficient & $\begin{array}{c}\mathbf{t}- \\
\text { statistic }\end{array}$ & $\begin{array}{c}\text { p- } \\
\text { value }\end{array}$ \\
\hline INTERCEPT & 1.558 & 0.409 & 0.685 & 1.153 & 0.305 & 0.762 & 1.623 & 0.445 & 0.658 \\
\hline IMP / AST & 0.328 & 0.029 & 0.977 & & & & & & \\
\hline IMP / EQT & & & & 2.501 & 0.414 & 0.681 & & & \\
\hline$I M P$ / GDW & & & & & & & -0.218 & -0.147 & 0.884 \\
\hline \multicolumn{10}{|l|}{ ROE } \\
\hline AVG.ROE & -0.465 & -0.394 & 0.696 & -0.576 & -0.479 & 0.635 & -0.450 & -0.383 & 0.704 \\
\hline A.C.MEET. & 0.279 & 0.681 & 0.500 & 0.220 & 0.556 & 0.581 & 0.290 & 0.792 & 0.433 \\
\hline A.C.IND.DIR. & -1.582 & -0.466 & 0.644 & -1.559 & -0.461 & 0.647 & -1.486 & -0.431 & 0.668 \\
\hline SIZE & 0.189 & 0.658 & 0.515 & 0.232 & 0.827 & 0.413 & 0.181 & 0.694 & 0.492 \\
\hline YEAR.07 & 1.221 & 1.687 & 0.100 & $* 1.244$ & 1.731 & 0.091 & $* 1.214$ & 1.691 & 0.099 \\
\hline YEAR.08 & $* * 1.577$ & 2.230 & 0.032 & $* * 1.547$ & 2.183 & 0.035 & $* * 1.601$ & 2.203 & 0.034 \\
\hline SECT.A & -0.012 & -0.012 & 0.991 & 0.030 & 0.030 & 0.976 & -0.035 & -0.035 & 0.973 \\
\hline SECT.B & 1.460 & 1.262 & 0.214 & 1.583 & 1.375 & 0.177 & 1.416 & 1.252 & 0.218 \\
\hline SECT.C & $* 2.332$ & 1.746 & 0.089 & $* 2.304$ & 1.727 & 0.092 & $* 2.307$ & 1.713 & 0.095 \\
\hline SECT.D & $* * *-3.002$ & -2.961 & 0.005 & $* * *-2.959$ & -2.932 & 0.006 & $* * *-3.026$ & -2.986 & 0.005 \\
\hline$n$ & \multicolumn{3}{|l|}{51} & \multicolumn{3}{|l|}{51} & \multicolumn{3}{|l|}{51} \\
\hline Adjusted $\mathbf{R}^{2}$ & \multicolumn{3}{|l|}{0.418} & \multicolumn{3}{|l|}{0.420} & \multicolumn{3}{|l|}{0.418} \\
\hline
\end{tabular}

Table 12. Multivariate Linear Regressions - British Companies

As in the Italian sample, the corporate governance related indicators exhibit insignificant associations.

\section{Discussion}

In a sample of firms with market indications of goodwill impairments, we find a relatively low frequency of write-offs. Only 27 of the 110 observed cases (25\% of the entire sample) record goodwill impairments, with a statistically insignificant difference between the Italian and the British cases.

Similarly, the level of disclosure on impairment test provided in the notes to the consolidated financial statements is relatively low, albeit the items identified to measure disclosure score 
are mandatory in accordance with the requirements of IAS 36.

Regarding the whole sample, with a maximum score that a company could achieve equal to 10 , the mean value of the level of disclosure does not reach 6 . There is no significant difference between 59 Italian cases (with a mean disclosure score equal to 5.5) and 51 British cases (with a mean disclosure score equal to 5.0).

However, as expected, the degree of disclosure tends to improve from 2006 to 2008, and it is influenced by firm sector.

Looking at the first research question (see $\mathrm{H} 1$ ), the results confirm that Italian companies provide more information about impairment test when goodwill is impaired, with the strength of the positive association between the level of disclosure and the magnitude of goodwill writeoffs across a variety of model specifications.

This finding suggests that the level of disclosure, as assumed, could represent a relevant indicator of the degree of reliability with which Italian companies have implemented IAS 36 requirements on goodwill impairment test.

In addition, to examine the second research question (see $\mathrm{H} 2$ ), the Italian data confirms, both in univariate and multivariate analysis, our hypothesis, finding a significant association between disclosure score and accounting performance in the predicted direction. In other words, Italian firms with lower return on equity ratio tend to provide less information about goodwill impairment test.

For British cases we assumed (see H3) a lower degree of positive association between the level of disclosure and the magnitude of goodwill impairments as well as the return on equity ratios.

Indeed, beyond expectation, the data of British sampled companies does not confirm that the level of disclosure is significantly associated with goodwill write-offs or accounting performance.

In summary, it should be noted that the general level of disclosure about goodwill impairment test provided by British companies, although not more satisfactory respect to the Italian cases, seems to be smoother, as it is less affected by managers' decision to take goodwill write-offs and less influenced by corporate accounting performance.

Our results suggest that despite the mandatory nature of disclosure requirements, there are significant variations in disclosure score across firms. Overall, the degree of information about goodwill impairment, in both the Italian and the British cases, is not influenced by the quality of the corporate governance. Both the level of activity of the audit committee, measured by 
the number of meeting held in year, and the percentage of the independent directors with an active role, identified by membership of the audit committee, do not exhibit significant associations with corporate disclosure of impairment tests.

These findings are consistent with those studies that specifically noted that the proportion of directors who are independent does not affect the quality of mandatory (Forker, 1992) or voluntary (Ho \& Wong, 2001; Brammer \& Pavelin, 2006) disclosure.

Indeed, as discussed earlier, the results of previous research regarding the association between board independence and the quality of corporate information are heterogeneous: some works provide evidence of a positive association between the two variables (Chen \& Jaggi, 2000), whilst others found a negative relationship (Eng \& Mak, 2003).

Thus the question remains whether independent directors contribute to increase mandatory or voluntary disclosure or whether they are ineffective (García-Meca \& Sánchez-Ballesta, 2010). Moreover, it should be noted that in practice it is rather difficult to classify independent directors as truly independent from management: as a consequence, some nominally independent directors may be valuable, while others are not (Di Pietra, Grambovas, Raonic \& Riccaboni, 2008).

On the other hand, with regard to the object of our research, an alternative or more specific explanation could be that the significant estimates required in order to assess the recoverable amount of goodwill stress the importance of director's inside perspective for improving the quality of control and disclosure. In particular, the certification of such information disclosure, also by the audit committee, necessarily requires some firm-specific expertise on the part of directors. Therefore, the independence of directors may reduce the ability to acquire firmspecific information inherent in impairment test assumptions (Biondi, Giannocolo \& Reberioux, 2010).

\section{Additional Analysis: The Last Years of IAS 36 Application}

Despite the objective of our study is to test the initial impact of IAS 36 in the first years of its application, it seems interesting to extent the analysis of the goodwill disclosure with reference to the last years of IAS 36 application. These additional research also represents a robustness test with reference to our previous findings.

As a consequence, we examine the 2011 and 2012 financial statements of the same Italian and British companies included in our sample, as defined in Section 4, also in order to verify if the positive trend of progressive improvement of goodwill disclosure is confirmed. 
Table 13 details the sample selection criteria for the years 2011 and 2012: our final sample consists of 82 financial statements.

\begin{tabular}{|l|r|r|r|}
\cline { 2 - 4 } \multicolumn{1}{c|}{} & Italian companies & British companies & Total \\
\hline $\begin{array}{l}\text { Number of the same companies included } \\
\text { in the final sample of our previous } \\
\text { analysis }\end{array}$ & 27 & 21 & 48 \\
\hline $\begin{array}{l}\text { First number of consolidated financial } \\
\text { statements 2011 - 2012 }\end{array}$ & 54 & 42 & 96 \\
\hline Less: & -2 & -6 & -8 \\
\hline $\begin{array}{l}\text { Financial statements of companies not } \\
\text { more listed }\end{array}$ & 0 & -5 & -5 \\
\hline $\begin{array}{l}\text { Financial statements with zero goodwill } \\
\text { value }\end{array}$ & -1 & 0 & -1 \\
\hline $\begin{array}{l}\text { Financial statements with negative book } \\
\text { value of equity }\end{array}$ & 51 & 31 & 82 \\
\hline Final sample & \multicolumn{2}{|c|}{} \\
\hline
\end{tabular}

Table 13. Sample Selection Procedure for The Years 2011-2012

Of our 82 observations, as shown in Table 14, only $26 \%$ record goodwill impairment. These results are very similar to the percentage $(25 \%)$ of non-impairment described in Section 5 with reference to the first years (2006-2008) of IAS application.

\begin{tabular}{|l|r|r|r|r|r|r|}
\cline { 2 - 6 } \multicolumn{1}{c|}{} & \multicolumn{2}{c|}{ Italian cases } & \multicolumn{2}{c|}{ British cases } & \multicolumn{2}{c|}{ Total } \\
\cline { 2 - 7 } \multicolumn{1}{c|}{} & \multicolumn{1}{c|}{$\boldsymbol{n}$} & \multicolumn{1}{c|}{$\%$} & \multicolumn{1}{c|}{$\boldsymbol{n}$} & \multicolumn{1}{c|}{$\%$} & \multicolumn{1}{c|}{$\boldsymbol{n}$} & \multicolumn{1}{c|}{$\%$} \\
\hline No goodwill impairment & 38 & $75 \%$ & 23 & $74 \%$ & 61 & $74 \%$ \\
\hline Goodwill impairment & 13 & $25 \%$ & 8 & $26 \%$ & 21 & $26 \%$ \\
\hline Total & 51 & $100 \%$ & 31 & $100 \%$ & 82 & $100 \%$ \\
\hline
\end{tabular}

The chi-square statistic for the table has a p-value of 0.975

Table 14. Frequency of Goodwill Impairments

Also in this additional time period of analysis we note that the chi-square statistic for the comparison of impairment frequency across firm country is not statistically significant ( $p$-value of 0.975 ), as the frequency of goodwill non-impairment in the Italian (51 cases) and British (31 cases) samples is almost the same (respectively, 25\% and 26\%).

Table 15, by analogy with Table 5, presents some descriptive statistics for all the variables, with reference to the Italian and British companies. We specify that now the variable AVG.ROE refers to the average ROE in the period 2011-2012.

As regards the disclosure quality, Panel 15A and Panel 15B provide evidence of improvement, confirming our hypothesis. The mean value of disclosure score is 6.9 in the Italian sample (equal to 5.5 in the period 2006-2008) and 6.1 with reference to the British observations (equal to 5.0 in the period 2006-2008). However, these results are still unsatisfactory, considering that all the ten items (Table 2) identified to measure the quality of corporate information about goodwill are mandatory. 


\begin{tabular}{|c|c|c|c|c|c|}
\hline \multicolumn{6}{|c|}{ Panel 15A: Italian Companies } \\
\hline Variable & Mean & Median & Minimum & Maximum & $\begin{array}{l}\text { Standard } \\
\text { deviation }\end{array}$ \\
\hline DISC & 6.922 & 8.000 & 0.000 & 10.000 & 2.407 \\
\hline IMP / AST & 0.001 & 0.000 & 0.000 & 0.025 & 0.004 \\
\hline IMP / EQT & 0.003 & 0.000 & 0.000 & 0.280 & 0.049 \\
\hline IMP / GDW & 0.016 & 0.000 & 0.000 & 0.280 & 0.049 \\
\hline ROE & 0.010 & 0.035 & -1.202 & 0.825 & 0.320 \\
\hline \multicolumn{2}{|l|}{ AVG.ROE } & 0.041 & -0.957 & 0.448 & 0.232 \\
\hline A.C.MEET. & 4.157 & 4.000 & 0.000 & 12.000 & 2.595 \\
\hline A.C.IND.DIR. & 0.234 & 0.231 & 0.000 & 0.429 & 0.099 \\
\hline SIZE & 13.225 & 12.813 & 10.594 & 16.258 & 1.522 \\
\hline \multicolumn{6}{|l|}{$n=51$} \\
\hline \multicolumn{6}{|c|}{ Panel 15B: British Companies } \\
\hline \multicolumn{2}{|c|}{ Variable } & Median & Minimum & Maximum & $\begin{array}{l}\text { Standard } \\
\text { deviation }\end{array}$ \\
\hline \multicolumn{2}{|l|}{ DISC } & 6.000 & 0.000 & 9.000 & 1.928 \\
\hline \multicolumn{2}{|l|}{ IMP / AST } & 0.000 & 0.000 & 0.084 & 0.018 \\
\hline \multirow{2}{*}{\multicolumn{2}{|c|}{$\begin{array}{l}\text { IMP / EQT } \\
\text { IMP / GDW }\end{array}$}} & 0.000 & 0.000 & 0.240 & 0.051 \\
\hline & 0.057 & 0.000 & 0.000 & 1.000 & 0.187 \\
\hline ROE & 0.079 & 0.105 & -0.402 & 0.448 & 0.156 \\
\hline \multicolumn{2}{|l|}{ AVG.ROE } & 0.114 & -0.380 & 0.225 & 0.139 \\
\hline \multicolumn{2}{|l|}{ A.C.MEET. } & 4.000 & 0.000 & 8.000 & 1.786 \\
\hline \multicolumn{2}{|l|}{ A.C.IND.DIR. } & 0.429 & 0.167 & 0.667 & 0.141 \\
\hline \multirow{2}{*}{\multicolumn{2}{|c|}{$\begin{array}{l}\text { SIZE } \\
n=31\end{array}$}} & 12.583 & 9.123 & 15.855 & 1.729 \\
\hline & & & & & \\
\hline \multicolumn{6}{|c|}{ Panel 15C: Italian and British Companies } \\
\hline \multirow[t]{2}{*}{ Variable } & $\begin{array}{c}\text { Italian cases } \\
(n=51)\end{array}$ & \multicolumn{2}{|c|}{$\begin{array}{c}\text { British cases } \\
(n=31)\end{array}$} & $\begin{array}{c}\text { Difference in } \\
\text { mean value }\end{array}$ & t-statistic ${ }^{a}$ \\
\hline & Mean & \multicolumn{2}{|c|}{ Mean } & & \\
\hline DISC & 6.922 & & 6.129 & 0.793 & 1.640 \\
\hline IMP / AST & 0.001 & & 0.006 & -0.005 & 1.278 \\
\hline IMP / EQT & 0.003 & & 0.016 & -0.013 & 1.314 \\
\hline IMP / GDW & 0.016 & & 0.057 & -0.041 & 1.211 \\
\hline ROE & 0.010 & & 0.079 & -0.069 & 1.305 \\
\hline AVG.ROE & 0.013 & & 0.079 & -0.066 & 1.590 \\
\hline A.C.MEET. & 4.157 & & 3.548 & 0.609 & 1.255 \\
\hline A.C.IND.DIR. & 0.234 & & 0.437 & -0.203 & $* * * 7.040$ \\
\hline SIZE & 13.225 & & 12.414 & 0.811 & $* * 2.154$ \\
\hline
\end{tabular}

${ }^{a}$ Significantly different at the 0.10 level (*), 0.05 level (**) or the 0.01 level (***).

Table 15. Descriptive Statistics

The comparison between the mean values of each variable, with reference, respectively, to the Italian and British observations for the period 2011-2012, is shown by Panel 15C. In particular, confirming the results of our previous analysis (see Panel $5 \mathrm{C}$ of Table 5), the difference in terms of disclosure is not significant, the mean value of firm size is significantly greater for the Italian cases and the proportion of independent directors is significantly greater for the British observations. 
Table 16 reports on the association between goodwill impairment and disclosure.

\begin{tabular}{|c|c|c|c|c|}
\hline \multicolumn{5}{|c|}{ Panel 16A: Italian companies - Total cases } \\
\hline Variable & $\begin{array}{c}\text { Cases without } \\
\text { goodwill impairment } \\
(n=38)\end{array}$ & $\begin{array}{c}\text { Cases with } \\
\text { goodwill impairment } \\
(n=13)\end{array}$ & $\begin{array}{c}\text { Difference } \\
\text { in mean } \\
\text { value } \\
\end{array}$ & t-statistic a \\
\hline & Mean & Mean & & \\
\hline DISC & 6.421 & 8.385 & -1.964 & $* * * 4.084$ \\
\hline \multicolumn{5}{|c|}{ Panel 16B: British companies - Total cases } \\
\hline Variable & $\begin{array}{c}\text { Cases without } \\
\text { goodwill impairment } \\
(n=23)\end{array}$ & $\begin{array}{c}\text { Cases with } \\
\text { goodwill impairment } \\
(n=8)\end{array}$ & $\begin{array}{l}\text { Difference } \\
\text { in mean } \\
\text { value }\end{array}$ & t-statistic ${ }^{a}$ \\
\hline & Mean & Mean & & \\
\hline DISC & 6.435 & 5.250 & 1.185 & 1.604 \\
\hline \multicolumn{5}{|c|}{ Panel 16C: Italian and British companies - Cases without goodwill impairment } \\
\hline Variable & $\begin{array}{l}\text { Italian companies } \\
\qquad(n=38)\end{array}$ & $\begin{array}{l}\text { British companies } \\
\qquad(n=23)\end{array}$ & $\begin{array}{c}\text { Difference } \\
\text { in mean } \\
\text { value }\end{array}$ & t-statistic ${ }^{a}$ \\
\hline & Mean & Mean & & \\
\hline DISC & 6.421 & 6.435 & -0.014 & 0.024 \\
\hline \multicolumn{5}{|c|}{ Panel 16D: Italian and British companies - Cases with goodwill impairment } \\
\hline Variable & $\begin{array}{l}\text { Italian companies } \\
\qquad(n=13)\end{array}$ & $\begin{array}{l}\text { British companies } \\
\qquad(n=8)\end{array}$ & $\begin{array}{c}\text { Difference } \\
\text { in mean } \\
\text { value } \\
\end{array}$ & t-statistic ${ }^{\text {a }}$ \\
\hline & Mean & Mean & & \\
\hline DISC & 8.385 & 5.250 & 3.135 & $* * * 4.714$ \\
\hline
\end{tabular}

a Significantly different at the 0.10 level $(*), 0.05$ level $(* *)$ or the 0.01 level $(* * *)$.

Table 16. Goodwill Impairment and Disclosure

Of particular interest, the results corroborate our findings for the period 2006-2008 (see Tabel 6): also in the last years of IAS 36 application only for the Italian sampled firms (Panel 16A) the mean score of disclosure is significantly greater (at the 0.01 level) with reference to the cases with goodwill impairment, confirming the positive assumed association between goodwill write-offs and level of disclosure.

Moreover, Panel 16D shows that the difference in mean score of disclosure among the Italian observations with goodwill write-offs is significantly (at the 0.01 level) greater than the mean value among the British impairment cases, as well as in the first years of IAS 36 application (see Panel 6D of Table 6).

Table 17, Table 18 and Table 19 provide Pearson correlation coefficients between variables for the entire sample, only the Italian cases and only the British observations respectively. 


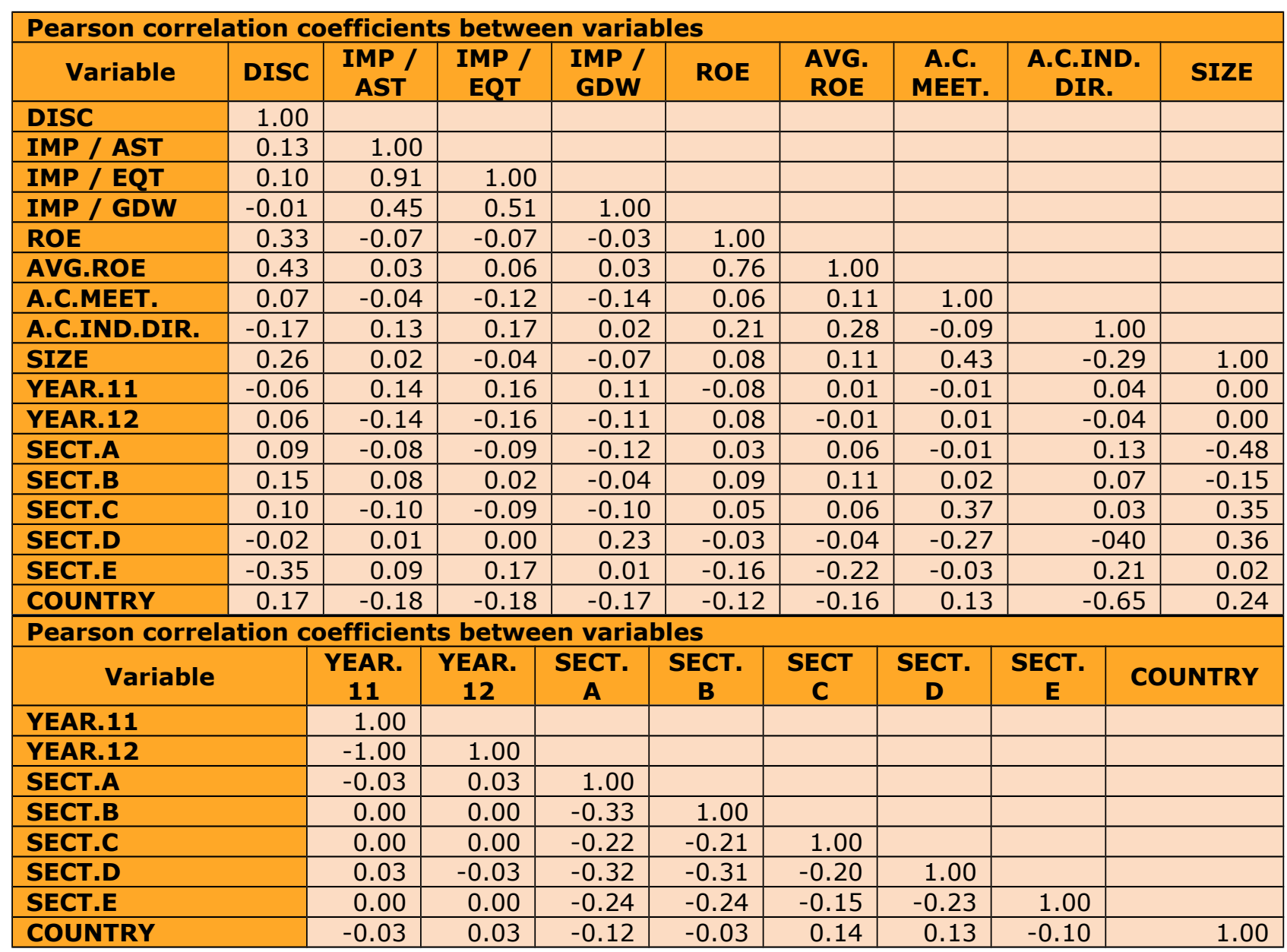

Table 17. Univariate Correlations - Italian and British Companies 


\begin{tabular}{|c|c|c|c|c|c|c|c|c|c|}
\hline \multicolumn{10}{|c|}{ Pearson correlation coefficients between variables } \\
\hline Variable & DISC & $\begin{array}{c}\text { IMP / } \\
\text { AST }\end{array}$ & $\begin{array}{l}\text { IMP / } \\
\text { EQT }\end{array}$ & $\begin{array}{l}\text { IMP / } \\
\text { GDW }\end{array}$ & ROE & $\begin{array}{l}\text { AVG. } \\
\text { ROE }\end{array}$ & $\begin{array}{l}\text { A.C. } \\
\text { MEET. }\end{array}$ & $\begin{array}{l}\text { A.C.IND. } \\
\text { DIR. }\end{array}$ & SIZE \\
\hline DISC & 1.00 & & & & & & & & \\
\hline IMP / AST & 0.32 & 1.00 & & & & & & & \\
\hline IMP / EQT & 0.33 & 0.99 & 1.00 & & & & & & \\
\hline IMP / GDW & 0.26 & 0.60 & 0.69 & 1.00 & & & & & \\
\hline ROE & 0.45 & -0.04 & -0.05 & -0.02 & 1.00 & & & & \\
\hline AVG.ROE & 0.59 & -0.01 & -0.01 & 0.05 & 0.73 & 1.00 & & & \\
\hline A.C.MEET. & 0.00 & 0.00 & 0.01 & -0.02 & 0.09 & 0.15 & 1.00 & & \\
\hline A.C.IND.DIR. & -0.20 & -0.25 & -0.23 & -0.19 & 0.09 & 0.14 & 0.19 & 1.00 & \\
\hline SIZE & 0.29 & 0.31 & 0.28 & 0.24 & 0.09 & 0.13 & 0.35 & -0.34 & 1.00 \\
\hline YEAR.11 & -0.10 & -0.03 & -0.03 & -0.09 & -0.06 & 0.01 & 0.00 & -0.04 & 0.04 \\
\hline YEAR.12 & 0.10 & 0.03 & 0.03 & 0.09 & 0.06 & -0.01 & 0.00 & 0.04 & -0.04 \\
\hline SECT.A & 0.06 & 0.01 & 0.02 & -0.12 & 0.11 & 0.19 & -0.03 & 0.24 & -0.47 \\
\hline SECT.B & 0.19 & -0.10 & -0.07 & 0.11 & 0.07 & 0.09 & -0.09 & 0.28 & -0.28 \\
\hline SECT.C & -0.03 & -0.14 & -0.14 & -0.14 & 0.03 & 0.04 & 0.41 & 0.24 & 0.27 \\
\hline SECT.D & 0.19 & 0.23 & 0.20 & 0.15 & 0.02 & 0.02 & -0.33 & -0.66 & 0.51 \\
\hline SECT.E & -0.55 & -0.03 & -0.05 & -0.06 & -0.30 & -0.42 & 0.14 & -0.03 & -0.03 \\
\hline \multicolumn{10}{|c|}{ Pearson correlation coefficients between variables } \\
\hline \multicolumn{3}{|c|}{ Variable } & $\begin{array}{l}\text { YEAR. } \\
11\end{array}$ & $\begin{array}{l}\text { YEAR. } \\
12\end{array}$ & $\begin{array}{l}\text { SECT. } \\
\text { A }\end{array}$ & $\begin{array}{l}\text { SECT. } \\
\text { B }\end{array}$ & $\begin{array}{l}\text { SECT. } \\
\text { C }\end{array}$ & $\begin{array}{l}\text { SECT. } \\
\text { D }\end{array}$ & $\begin{array}{c}\text { SECT. } \\
\text { E }\end{array}$ \\
\hline \multicolumn{3}{|l|}{ YEAR.11 } & 1.00 & & & & & & \\
\hline \multicolumn{3}{|l|}{ YEAR.12 } & -1.00 & 1.00 & & & & & \\
\hline \multicolumn{3}{|l|}{ SECT.A } & -0.04 & 0.04 & 1.00 & & & & \\
\hline \multicolumn{3}{|l|}{ SECT.B } & 0.01 & -0.01 & -0.29 & 1.00 & & & \\
\hline \multicolumn{3}{|l|}{ SECT.C } & 0.01 & -0.01 & -0.23 & -0.24 & 1.00 & & \\
\hline \multicolumn{3}{|l|}{ SECT.D } & 0.01 & -0.01 & -0.32 & -0.34 & -0.27 & 1.00 & \\
\hline \multicolumn{3}{|l|}{ SECT.E } & 0.01 & -0.01 & -0.19 & -0.20 & -0.16 & -0.22 & 1.00 \\
\hline
\end{tabular}

Table 18. Univariate Correlations - Italian Companies 


\begin{tabular}{|c|c|c|c|c|c|c|c|c|c|}
\hline \multicolumn{10}{|c|}{ Pearson correlation coefficients between variables } \\
\hline Variable & DISC & $\begin{array}{c}\text { IMP / } \\
\text { AST }\end{array}$ & $\begin{array}{c}\text { IMP / } \\
\text { EQT }\end{array}$ & $\begin{array}{c}\text { IMP / } \\
\text { GDW }\end{array}$ & ROE & $\begin{array}{l}\text { AVG. } \\
\text { ROE }\end{array}$ & $\begin{array}{c}\text { A.C. } \\
\text { MEET. }\end{array}$ & $\begin{array}{l}\text { A.C.IND. } \\
\text { DIR. }\end{array}$ & SIZE \\
\hline DISC & 1.00 & & & & & & & & \\
\hline IMP / AST & 0.16 & 1.00 & & & & & & & \\
\hline IMP / EQT & 0.13 & 0.91 & 1.00 & & & & & & \\
\hline IMP / GDW & -0.11 & 0.41 & 0.48 & 1.00 & & & & & \\
\hline ROE & 0.03 & -0.25 & -0.25 & -0.14 & 1.00 & & & & \\
\hline AVG.ROE & 0.07 & 0.01 & 0.07 & -0.03 & 0.89 & 1.00 & & & \\
\hline A.C.MEET. & 0.22 & -0.04 & -0.22 & -0.26 & 0.01 & 0.05 & 1.00 & & \\
\hline A.C.IND.DIR. & 0.09 & 0.09 & 0.14 & -0.11 & 0.44 & 0.48 & -0.34 & 1.00 & \\
\hline SIZE & 0.14 & 0.00 & -0.08 & -0.14 & 0.20 & 0.23 & 0.59 & -0.02 & 1.00 \\
\hline YEAR.11 & 0.03 & 0.25 & 0.27 & 0.23 & -0.18 & -0.01 & -0.03 & 0.12 & -0.04 \\
\hline YEAR.12 & -0.03 & -0.25 & -0.27 & -0.23 & 0.18 & 0.01 & 0.03 & -0.12 & 0.04 \\
\hline SECT.A & 0.21 & -0.17 & -0.19 & -0.18 & -0.26 & -0.30 & 0.10 & -0.11 & -0.46 \\
\hline SECT.B & 0.08 & 0.16 & 0.04 & -0.12 & 0.16 & 0.18 & 0.28 & -0.17 & 0.03 \\
\hline SECT.C & 0.40 & -0.08 & -0.08 & -0.08 & 0.25 & 0.28 & 0.14 & 0.07 & 0.51 \\
\hline SECT.D & -0.63 & -0.04 & -0.02 & 0.41 & -0.14 & -0.16 & -0.19 & -0.13 & 0.05 \\
\hline SECT.E & 0.01 & 0.12 & 0.25 & 0.01 & 0.11 & 0.12 & -0.34 & 0.39 & 0.14 \\
\hline \multicolumn{10}{|c|}{ Pearson correlation coefficients between variables } \\
\hline \multicolumn{3}{|c|}{ Variable } & $\begin{array}{c}\text { YEAR. } \\
11 \\
\end{array}$ & $\begin{array}{c}\text { YEAR. } \\
12 \\
\end{array}$ & $\begin{array}{c}\text { SECT. } \\
\text { A }\end{array}$ & $\begin{array}{c}\text { SECT. } \\
\text { B }\end{array}$ & $\begin{array}{c}\text { SECT. } \\
\text { C }\end{array}$ & $\begin{array}{c}\text { SECT. } \\
\text { D }\end{array}$ & $\begin{array}{c}\text { SECT. } \\
\text { E }\end{array}$ \\
\hline \multicolumn{3}{|l|}{ YEAR.11 } & 1.00 & & & & & & \\
\hline \multicolumn{3}{|l|}{ YEAR.12 } & -1.00 & 1.00 & & & & & \\
\hline \multicolumn{3}{|l|}{ SECT.A } & -0.02 & 0.02 & 1.00 & & & & \\
\hline \multicolumn{3}{|l|}{ SECT.B } & -0.02 & 0.02 & -0.41 & 1.00 & & & \\
\hline \multicolumn{3}{|l|}{ SECT.C } & -0.01 & 0.01 & -0.18 & -0.15 & 1.00 & & \\
\hline \multicolumn{3}{|l|}{ SECT.D } & 0.07 & -0.07 & -0.30 & -0.26 & -0.12 & 1.00 & \\
\hline \multicolumn{3}{|l|}{ SECT.E } & -0.02 & 0.02 & -0.34 & -0.29 & -0.13 & -0.21 & 1.00 \\
\hline
\end{tabular}

Table 19. Univariate Correlations - British Companies

As predicted, we note also for the period 2011-2012 the positive correlations between the variables related to goodwill impairment and the disclosure score in particular (Table 18) with reference to the Italian sample (with Pearson coefficients equal to $0.32,0.33$ and 0.26 respectively for IMP/AST, IMP/EQT and IMP/GDW). Both profitability ratios are positively correlated with the disclosure score (with coefficients that in the Italian sample reach 0.45 and 0.59 respectively for ROE and AVG.ROE), also supporting our hypotheses. In all the three tables the level of disclosure is positively correlated also with firm size.

Finally, we conducted regression tests by applying for the period 2011-2012 the same six models defined in Section 4.

Table 20 reports on multivariate tests of the determinants of corporate disclosure in the Italian and British sample. 


\begin{tabular}{|c|c|c|c|c|c|c|c|c|c|}
\hline \multicolumn{10}{|c|}{ Dependent variable: DISC } \\
\hline \multirow[b]{2}{*}{ Variable } & \multicolumn{3}{|c|}{ Model 1} & \multicolumn{3}{|c|}{ Model 2} & \multicolumn{3}{|c|}{ Model 3} \\
\hline & Coefficient & $\begin{array}{c}\mathbf{t}- \\
\text { statistic }\end{array}$ & $\begin{array}{c}\text { p- } \\
\text { value }\end{array}$ & Coefficient & $\begin{array}{c}\mathrm{t}- \\
\text { statistic }\end{array}$ & $\begin{array}{c}\text { p- } \\
\text { value }\end{array}$ & Coefficient & $\begin{array}{c}\mathrm{t}- \\
\text { statistic }\end{array}$ & $\begin{array}{c}\text { p- } \\
\text { value }\end{array}$ \\
\hline Intercept & -3.364 & -1.265 & 0.210 & -3.858 & -1.466 & 0.147 & -4.375 & -1.577 & 0.119 \\
\hline IMP / AST & $* * 39.722$ & 2.177 & 0.033 & & & & & & \\
\hline$I M P$ / EQT & & & & $* * 16.470$ & 2.542 & 0.013 & & & \\
\hline$I M P$ / GDW & & & & & & & 2.500 & 1.370 & 0.175 \\
\hline ROE & $* * * 2.476$ & 3.079 & 0.003 & $2.448 * * *$ & 3.086 & 0.003 & $2.306 * * *$ & 2.826 & 0.006 \\
\hline \multicolumn{10}{|l|}{ AVG.ROE } \\
\hline A.C.MEET. & $* *-0.284$ & -2.450 & 0.017 & $-0.272 * *$ & -2.365 & 0.021 & $-0.297 * *$ & -2.510 & 0.014 \\
\hline A.C.IND.DIR. & -2.905 & -1.420 & 0.160 & -3.022 & -1.493 & 0.140 & -2.573 & -1.235 & 0.221 \\
\hline SIZE & $* * * 0.770$ & 3.953 & 0.000 & $0.796 * * *$ & 4.150 & 0.000 & $0.853 * * *$ & 4.247 & 0.000 \\
\hline YEAR.12 & 0.197 & 0.484 & 0.630 & 0.233 & 0.575 & 0.567 & 0.142 & 0.341 & 0.734 \\
\hline SECT.A & $* * * 3.056$ & 4.138 & 0.000 & $3.235 * * *$ & 4.395 & 0.000 & $3.121 * * *$ & 4.113 & 0.000 \\
\hline SECT.B & $* * * 2.385$ & 3.407 & 0.001 & $2.566 * * *$ & 3.697 & 0.000 & $2.471 * * *$ & 3.459 & 0.001 \\
\hline SECT.C & $* 1.603$ & 1.913 & 0.060 & $1.671 * *$ & 2.014 & 0.048 & $1.432 *$ & 1.685 & 0.097 \\
\hline SECT.D & -0.009 & -0.012 & 0.991 & 0.096 & 0.122 & 0.903 & -0.222 & -0.270 & 0.788 \\
\hline COUNTRY & 0.317 & 0.555 & 0.581 & 0.301 & 0.535 & 0.595 & 0.301 & 0.513 & 0.609 \\
\hline$n$ & \multicolumn{3}{|l|}{82} & \multicolumn{3}{|l|}{82} & \multicolumn{3}{|l|}{82} \\
\hline Adjusted $\mathbf{R}^{2}$ & 0.351 & & & 0.366 & & & 0.325 & & \\
\hline \multirow[b]{2}{*}{ Variable } & \multicolumn{3}{|c|}{ Model 4} & \multicolumn{3}{|c|}{ Model 5} & \multicolumn{3}{|c|}{ Model 6} \\
\hline & Coefficient & $\begin{array}{c}\mathrm{t}- \\
\text { statistic }\end{array}$ & $\begin{array}{c}\text { p- } \\
\text { value }\end{array}$ & Coefficient & $\begin{array}{c}\mathrm{t}- \\
\text { statistic }\end{array}$ & $\begin{array}{c}\text { p- } \\
\text { value }\end{array}$ & Coefficient & $\begin{array}{c}\mathrm{t}- \\
\text { statistic }\end{array}$ & $\begin{array}{c}\text { p- } \\
\text { value }\end{array}$ \\
\hline Intercept & -1.779 & -0.681 & 0.498 & -2.301 & -0.882 & 0.381 & -2.561 & -0.937 & 0.352 \\
\hline IMP / AST & $* 34.634$ & 1.997 & 0.050 & & & & & & \\
\hline IMP / EQT & & & & $* * 13.368$ & 2.145 & 0.035 & & & \\
\hline IMP / GDW & & & & & & & 1.985 & 1.137 & 0.260 \\
\hline \multicolumn{10}{|l|}{ ROE } \\
\hline AVG.ROE & $* * * 4.460$ & 4.137 & 0.000 & $* * * 4.292$ & 3.989 & 0.000 & $* * * 4.356$ & 3.956 & 0.000 \\
\hline A.C.MEET. & $* * *-0.302$ & -2.722 & 0.008 & $* *-0.291$ & -2.633 & 0.010 & $* * *-0.312$ & -2.760 & 0.007 \\
\hline A.C.IND.DIR. & $* *-4.145$ & -2.063 & 0.043 & $* *-4.143$ & -2.071 & 0.042 & $*-3.887$ & -1.896 & 0.062 \\
\hline SIZE & $* * * 0.702$ & 3.739 & 0.000 & $* * * 0.731$ & 3.916 & 0.000 & $* * * 0.769$ & 3.961 & 0.000 \\
\hline YEAR.12 & 0.296 & 0.761 & 0.449 & 0.316 & 0.815 & 0.418 & 0.235 & 0.597 & 0.553 \\
\hline SECT.A & $* * * 2.610$ & 3.602 & 0.001 & $* * * 2.779$ & 3.805 & 0.000 & $* * * 2.649$ & 3.553 & 0.001 \\
\hline SECT.B & $* * * 1.992$ & 2.907 & 0.005 & $* * * 2.168$ & 3.156 & 0.002 & $* * * 2.055$ & 2.936 & 0.004 \\
\hline SECT.C & $* 1.387$ & 1.725 & 0.089 & $* 1.447$ & 1.800 & 0.076 & 1.232 & 1.512 & 0.135 \\
\hline SECT.D & -0.364 & -0.472 & 0.639 & -0.257 & -0.333 & 0.740 & -0.542 & -0.683 & 0.497 \\
\hline COUNTRY & 0.230 & 0.421 & 0.675 & 0.212 & 0.391 & 0.697 & 0.207 & 0.369 & 0.713 \\
\hline$n$ & \multicolumn{3}{|l|}{82} & \multicolumn{3}{|l|}{82} & \multicolumn{3}{|l|}{82} \\
\hline Adjusted $\mathbf{R}^{2}$ & \multicolumn{3}{|l|}{0.408} & \multicolumn{3}{|l|}{0.413} & \multicolumn{3}{|l|}{0.385} \\
\hline
\end{tabular}

Table 20. Multivariate Linear Regressions - Italian and British Companies

The maximum VIF is equal to only 2.928 , so confirming that multicollinearity among the predictor variables is not a problem; the analysis of the residuals through the Durbin-Watson test does not provide evidence of autocorrelation.

The multiple linear regressions show results very similar to those recorded with reference to the first period of IAS 36 application (see Table 10), providing further evidence of the robustness of our findings. 
In summary, with reference to the period 2011-2012 too:

- the association between goodwill impairment and the dependent variable DISC is significant in the predicted sense (see H1) in four models (Model 1, Model 2, Model 4 and Model 5);

- the disclosure level is significantly and positively associated, as expected (see $\mathrm{H} 2$ ), also with the alternative profitability ratios in all the six models.

In all six regressions the model adjusted $\mathrm{R} 2$ is higher than 0.3 .

Furthermore, all six models show that the level of disclosure is significantly associated in the prediction sense with firm size. We also note some significant coefficients referred to the majority of the activity sectors and corporate governance variables.

Other similar regression models, not presented in Table 20, show negative but insignificant coefficients associated with dummy variable YEAR.2011, and positive but insignificant coefficients on dummy variable SECT.E.

Table 21 and Table 22 examine separately the two samples of Italian and British firms respectively, providing evidence that also in the period 2011-2012 the results have been affected by inclusion of Italian company, so confirming our third research question too (see H3). The largest VIF score, equal to 4.578 (Table 21) and 6.935 (Table 22) confirm that multicollinearity does not represent a problem and the analysis of the residuals through the Durbin-Watson test does not provide evidence of autocorrelation. 


\begin{tabular}{|c|c|c|c|c|c|c|c|c|c|}
\hline \multicolumn{10}{|c|}{ Dependent variable: DISC } \\
\hline \multirow[b]{2}{*}{ Variable } & \multicolumn{3}{|c|}{ Model 1a } & \multicolumn{3}{|c|}{ Model 2a } & \multicolumn{3}{|c|}{ Model 3a } \\
\hline & Coefficient & $\begin{array}{c}\text { t- } \\
\text { statistic }\end{array}$ & $\begin{array}{c}\mathrm{p}- \\
\text { value }\end{array}$ & Coefficient & $\begin{array}{c}\mathbf{t}- \\
\text { statistic }\end{array}$ & $\begin{array}{c}\text { p- } \\
\text { value }\end{array}$ & Coefficient & $\begin{array}{c}\text { t- } \\
\text { statistic }\end{array}$ & $\begin{array}{c}\text { p- } \\
\text { value }\end{array}$ \\
\hline Intercept & -3.379 & -0.988 & 0.329 & -3.448 & -1.011 & 0.318 & -4.557 & -1.313 & 0.197 \\
\hline IMP / AST & $* 101.634$ & 1.724 & 0.092 & & & & & & \\
\hline IMP / EQT & & & & $* 44.708$ & 1.717 & 0.094 & & & \\
\hline$I M P$ / GDW & & & & & & & 3.785 & 0.705 & 0.485 \\
\hline ROE & $* * * 2.190$ & 2.808 & 0.008 & $* * * 2.205$ & 2.823 & 0.007 & $* * 2.085$ & 2.603 & 0.013 \\
\hline \multicolumn{10}{|l|}{ AVG.ROE } \\
\hline A.C.MEET. & -0.106 & -0.851 & 0.400 & -0.110 & -0.881 & 0.383 & -0.117 & -0.906 & 0.370 \\
\hline A.C.IND.DIR. & $* *-8.048$ & -2.480 & 0.017 & $* *-8.036$ & -2.475 & 0.018 & $* *-8.455$ & -2.525 & 0.016 \\
\hline SIZE & $* * 0.710$ & 2.597 & 0.013 & $* * 0.718$ & 2.639 & 0.012 & $* * * 0.816$ & 2.946 & 0.005 \\
\hline YEAR.12 & 0.463 & 1.007 & 0.320 & 0.467 & 1.016 & 0.316 & 0.469 & 0.985 & 0.330 \\
\hline SECT.A & $* * * 4.226$ & 4.471 & 0.000 & $* * * 4.197$ & 4.423 & 0.000 & $* * * 4.453$ & 4.623 & 0.000 \\
\hline SECT.B & $* * * 4.535$ & 5.114 & 0.000 & $* * * 4.486$ & 5.041 & 0.000 & $* * * 4.529$ & 4.882 & 0.000 \\
\hline SECT.C & $* * * 2.789$ & 2.940 & 0.005 & $* * * 2.761$ & 2.915 & 0.006 & $* * * 2.669$ & 2.740 & 0.009 \\
\hline SECT.D & 1.491 & 1.409 & 0.167 & 1.471 & 1.391 & 0.172 & 1.438 & 1.319 & 0.195 \\
\hline$n$ & \multicolumn{3}{|l|}{51} & \multicolumn{3}{|l|}{51} & \multicolumn{3}{|l|}{51} \\
\hline Adjusted $\mathbf{R}^{2}$ & \multicolumn{3}{|l|}{0.542} & \multicolumn{3}{|l|}{0.542} & \multicolumn{3}{|l|}{0.514} \\
\hline \multirow[b]{2}{*}{ Variable } & \multicolumn{3}{|c|}{ Model 4a } & \multicolumn{3}{|c|}{ Model 5a } & \multicolumn{3}{|c|}{ Model 6a } \\
\hline & Coefficient & $\begin{array}{c}\mathrm{t}- \\
\text { statistic }\end{array}$ & $\begin{array}{c}\text { p- } \\
\text { value }\end{array}$ & Coefficient & $\begin{array}{c}\mathrm{t}- \\
\text { statistic }\end{array}$ & $\begin{array}{c}\text { p- } \\
\text { value }\end{array}$ & Coefficient & $\begin{array}{c}\text { t- } \\
\text { statistic }\end{array}$ & $\begin{array}{c}\text { p- } \\
\text { value }\end{array}$ \\
\hline Intercept & -1.067 & -0.335 & 0.740 & -1.166 & -0.366 & 0.716 & -2.591 & -0.793 & 0.432 \\
\hline IMP / AST & $* 106.875$ & 2.005 & 0.052 & & & & & & \\
\hline IMP / EQT & & & & $* 46.553$ & 1.977 & 0.055 & & & \\
\hline$I M P$ / GDW & & & & & & & 2.808 & 0.572 & 0.571 \\
\hline \multicolumn{10}{|l|}{ ROE } \\
\hline AVG.ROE & $* * * 4.589$ & 4.297 & 0.000 & $* * * 4.595$ & 4.295 & 0.000 & $* * * 4.371$ & 3.939 & 0.000 \\
\hline A.C.MEET. & -0.151 & -1.323 & 0.193 & -0.155 & -1.357 & 0.182 & -0.162 & -1.361 & 0.181 \\
\hline A.C.IND.DIR. & $* * *-9.123$ & -3.088 & 0.004 & $* * *-9.117$ & -3.081 & 0.004 & $* * *-9.612$ & -3.103 & 0.004 \\
\hline SIZE & $0.611 * *$ & 2.446 & 0.019 & $* * 0.621$ & 2.497 & 0.017 & $* * * 0.743$ & 2.909 & 0.006 \\
\hline YEAR.12 & 0.583 & 1.405 & 0.168 & 0.588 & 1.417 & 0.164 & 0.596 & 1.368 & 0.179 \\
\hline SECT.A & $* * * 3.231$ & 3.522 & 0.001 & $* * * 3.207$ & 3.480 & 0.001 & $* * * 3.534$ & 3.740 & 0.001 \\
\hline SECT.B & $* * * 3.750$ & 4.440 & 0.000 & $* * * 3.702$ & 4.365 & 0.000 & $* * * 3.812$ & 4.279 & 0.000 \\
\hline SECT.C & $* * 2.349$ & 2.697 & 0.010 & $* * 2.320$ & 2.664 & 0.011 & $* * 2.227$ & 2.451 & 0.019 \\
\hline SECT.D & 0.755 & 0.765 & 0.449 & 0.736 & 0.744 & 0.461 & 0.715 & 0.691 & 0.493 \\
\hline$n$ & \multicolumn{3}{|l|}{51} & \multicolumn{3}{|l|}{51} & \multicolumn{3}{|l|}{51} \\
\hline Adjusted $\mathbf{R}^{2}$ & \multicolumn{3}{|l|}{0.625} & \multicolumn{3}{|l|}{0.624} & \multicolumn{3}{|l|}{0.591} \\
\hline
\end{tabular}

* Significant at the 0.10 level; ** significant at the 0.05 level; *** significant at the 0.01 level.

Table 21. Multivariate Linear Regressions - Italian Companies 


\begin{tabular}{|c|c|c|c|c|c|c|c|c|c|}
\hline \multicolumn{10}{|c|}{ Dependent variable: DISC } \\
\hline \multirow[b]{2}{*}{ Variable } & \multicolumn{3}{|c|}{ Model 1b } & \multicolumn{3}{|c|}{ Model 2b } & \multicolumn{3}{|c|}{ Model 3b } \\
\hline & $\underset{t}{\text { Coefficien }}$ & $\begin{array}{c}\mathrm{t}- \\
\text { statistic }\end{array}$ & $\begin{array}{c}\text { p- } \\
\text { value }\end{array}$ & Coefficient & $\begin{array}{c}\mathrm{t}- \\
\text { statistic }\end{array}$ & $\begin{array}{c}\text { p- } \\
\text { value }\end{array}$ & Coefficient & $\begin{array}{c}\mathrm{t}- \\
\text { statistic }\end{array}$ & $\begin{array}{c}\text { p- } \\
\text { value }\end{array}$ \\
\hline Intercept & 5.165 & 1.061 & 0.301 & 4.857 & 0.995 & 0.331 & 3.482 & 0.711 & 0.485 \\
\hline IMP / AST & 16.674 & 0.910 & 0.374 & & & & & & \\
\hline IMP / EQT & & & & 6.254 & 0.950 & 0.353 & & & \\
\hline$I M P$ / GDW & & & & & & & 2.549 & 1.433 & 0.167 \\
\hline ROE & -1.230 & -0.493 & 0.628 & -1.221 & -0.492 & 0.628 & -2.100 & -0.926 & 0.366 \\
\hline \multicolumn{10}{|l|}{ AVG.ROE } \\
\hline A.C.MEET. & 0.059 & 0.161 & 0.874 & 0.082 & 0.224 & 0.825 & 0.066 & 0.185 & 0.855 \\
\hline A.C.IND.DIR. & 0.923 & 0.331 & 0.744 & 1.023 & 0.371 & 0.715 & 2.115 & 0.787 & 0.440 \\
\hline SIZE & 0,028 & 0.065 & 0.949 & 0.035 & 0.082 & 0.935 & 0.110 & 0.261 & 0.797 \\
\hline YEAR.12 & -0.056 & -0.092 & 0.928 & -0.035 & -0.057 & 0.955 & 0.059 & 0.098 & 0.923 \\
\hline SECT.A & 0,642 & 0.446 & 0.661 & 0.735 & 0.506 & 0.618 & 0.834 & 0.591 & 0.561 \\
\hline SECT.B & 0.237 & 0.192 & 0.850 & 0.354 & 0.287 & 0.777 & 0.559 & 0.462 & 0.649 \\
\hline SECT.C & $* 2.998$ & 2.010 & 0.058 & *3.026 & 2.031 & 0.056 & $* 2.932$ & 2.022 & 0.057 \\
\hline SECT.D & $* *-2.657$ & -2.555 & 0.019 & $* *-2.570$ & -2.445 & 0.024 & $* * *-3.042$ & -2.969 & 0.008 \\
\hline$N$ & \multicolumn{3}{|l|}{31} & \multicolumn{3}{|l|}{31} & \multicolumn{3}{|l|}{31} \\
\hline Adjusted $\mathbf{R}^{2}$ & \multicolumn{3}{|l|}{0.340} & \multicolumn{3}{|l|}{0.342} & \multicolumn{3}{|l|}{0.376} \\
\hline \multirow[b]{2}{*}{ Variable } & \multicolumn{3}{|c|}{ Model 4b } & \multicolumn{3}{|c|}{ Model 5b } & \multicolumn{3}{|c|}{ Model 6b } \\
\hline & Coefficient & $\begin{array}{c}\mathrm{t}- \\
\text { statistic }\end{array}$ & $\begin{array}{c}\text { p- } \\
\text { value }\end{array}$ & Coefficient & $\begin{array}{c}\mathrm{t}- \\
\text { statistic }\end{array}$ & $\begin{array}{c}\text { p- } \\
\text { value }\end{array}$ & Coefficient & $\begin{array}{c}\mathbf{t}- \\
\text { statistic }\end{array}$ & $\begin{array}{c}\text { p- } \\
\text { value }\end{array}$ \\
\hline Intercept & 5.296 & 1.098 & 0.285 & 4.902 & 1.019 & 0.321 & 3.580 & 0.737 & 0.469 \\
\hline IMP / AST & 18.972 & 1.114 & 0.278 & & & & & & \\
\hline IMP / EQT & & & & 7.622 & 1.251 & 0.225 & & & \\
\hline IMP / GDW & & & & & & & 2.799 & 1.568 & 0.132 \\
\hline \multicolumn{10}{|l|}{ ROE } \\
\hline AVG.ROE & -2.049 & -0.758 & 0.457 & -2.413 & -0.901 & 0.379 & -2.867 & -1.082 & 0.292 \\
\hline A.C.MEET. & 0.092 & 0.248 & 0.806 & 0.130 & 0.353 & 0.728 & 0.104 & 0.289 & 0.775 \\
\hline A.C.IND.DIR. & 1.324 & 0.476 & 0.639 & 1.646 & 0.598 & 0.557 & 2.530 & 0.912 & 0.372 \\
\hline SIZE & 0.001 & 0.003 & 0.998 & 0.003 & 0.007 & 0.995 & 0.086 & 0.206 & 0.839 \\
\hline YEAR.12 & -0.083 & -0.141 & 0.889 & -0.037 & -0.062 & 0.951 & -0.017 & -0.030 & 0.977 \\
\hline SECT.A & 0.548 & 0.381 & 0.707 & 0.638 & 0.445 & 0.661 & 0.738 & 0.524 & 0.606 \\
\hline SECT.B & 0.225 & 0.185 & 0.855 & 0.376 & 0.310 & 0.760 & 0.552 & 0.460 & 0.651 \\
\hline SECT.C & *3.148 & 2.097 & 0.049 & $* * 3.251$ & 2.172 & 0.042 & $* * 3.050$ & 2.096 & 0.049 \\
\hline SECT.D & $* *-2.677$ & -2.593 & 0.017 & $* *-2.568$ & -2.480 & 0.022 & $* * *-3.118$ & -3.058 & 0.006 \\
\hline$N$ & \multicolumn{3}{|l|}{31} & \multicolumn{3}{|l|}{31} & \multicolumn{3}{|l|}{31} \\
\hline Adjusted $\mathbf{R}^{2}$ & \multicolumn{3}{|l|}{0.350} & \multicolumn{3}{|l|}{0.360} & \multicolumn{3}{|l|}{0.385} \\
\hline
\end{tabular}

Table 22. Multivariate Linear Regressions - British Companies

As expected, only in the Italian sample (Table 21) the multiple linear regressions shows positive and significant associations both between disclosure and goodwill impairment and between disclosure and earnings performance, with the model adjusted R2 always higher than 0.50. On the other hand, with reference to the British cases (Table 22), in all the six models the corresponding coefficients are not significant, confirming the results of our preceding analysis. 


\section{Conclusions}

Previous research of goodwill write-offs determinants does not find univocal results, failing to provide strong evidence on identifying specific factors able to have clear predictive ability for goodwill impairments. Such limited significance of several variables, included stock prices and performance indicators, emerging in this empirical context seems due, on the one hand, to the information asymmetry between managers and other stakeholders and, on the other hand, to the cause that the factors treated by most of literature pertain to the firm as a whole rather than to the specific cash generating unit to which each goodwill has to be allocated (Hayn \& Hughes, 2006).

However, a few studies find evidence that non-impairment is associated with agency-based motives, especially firms' debt contracting and management bonus, and is increasing in financial characteristics, as number or size of reporting units and unverifiable net assets in reporting units, that serve as proxies for greater unverifiable fair value discretion.

This paper analyses this issue in the context of Italian and British firms' goodwill accounting, exploiting an accounting regulation that allows significant unverifiable estimates whilst at the same time one that requires a high level of disclosure.

Using a sample of firms with market indications of impairment in 2006 - 2008, our research investigates questions still relatively unexplored, concerning the effects of goodwill write-offs and accounting performance on corporate disclosure about goodwill impairment test.

Based on this analysis, this paper puts forward the view, and shows, that corporate disclosure could be a "litmus paper" able to test the degree of good faith with which each firm has implemented IAS 36 requirements on goodwill impairment test.

We provide empirical evidence on two aspects of such firms' mandatory disclosure: (1) whether the level of disclosure is positively related to the magnitude of goodwill write-off and (2) whether the level of disclosure is positively related to earnings performance.

For both questions, we use a self-constructed score of mandatory disclosure about goodwill impairment tests in accordance with IAS 36 requirements.

For the sampled Italian firms, as assumed, we find a significant and positive association both between impairment disclosure and goodwill write-offs, and between impairment disclosure and accounting performance. It should be noted that our results are generally independent of alternative measures of goodwill impairments and earnings performance. 
In summary, this study shows that impairment disclosure is negatively influenced by two negative factors:

- managers' decision to avoid goodwill write-offs despite of market indications of impairment;

- a decrease of corporate accounting performance.

For the sampled British firms, as companies more used to impairment test rules, we assumed a lower degree of both associations. The data, beyond expectation, does not confirm that the level of disclosure is significantly associated to goodwill write-offs or earnings performance. However, the British disclosure score is not more satisfactory than the Italian cases.

Indeed, the level of disclosure on impairment test provided by Italian and British firms is relatively low, albeit the items identified to measure disclosure score are mandatory in accordance with the requirements of IAS 36. On the other hand, the data provides evidence on a significant disclosure improvement with reference to the last observed year (2008).

The additional analysis that we conducted with reference to the last years of IAS 36 application (2011-2012), in order to test the robustness of our findings, confirms our previous results and provides evidence of better but still unsatisfactory disclosure.

Overall, the level of information is not influenced by the quality of corporate governance: specifically, we noted that firm-specific expertise, strictly required in order to identify and control the chain of significant estimates on which an impairment test is based, could be more difficult to obtain for independent directors (Biondi et al., 2010).

However, it has to be added that the number of activity sectors considered in our study is limited. Future research could usefully investigate the impact of goodwill impairment and accounting performance on corporate disclosure in a wider sample of firms, also extending the time period of analysis. In any case, the findings of our study are consistent with the insights of earnings management theory, suggesting that the various and differing profiles of subjectivity inherent in impairment test assumptions could be used opportunistically by managers.

In this context, our results highlight the role of an adequate disclosure, especially in periods, as our time, of strong market instability, which makes fair value measurements even more difficult (Quagli, 2009). This also concerns the relevant assumptions inherent in the goodwill impairment test as an indirect test based on potential upward valuations of reporting units and their net assets (Ramanna \& Watts, 2012). 


\section{References}

AHMED, A.S.; GULER, L. (2007). Evidence on the Effects of SFAS 142 on the Reliability of Goodwill Write-offs. Texas A \& M University, Working Paper, available at: http://ssrn.com/abstract=989056 [consulted: ]uly, 2011.

ASB (1997). FRS 10 - Goodwill and Intangible Assets. London: Accounting Standards Board.

BEATTY, A.; WEBER, J. (2006). Accounting Discretion in Fair Value Estimates: An Examination of SFAS 142 Goodwill Impairments. Journal of Accounting Research, 44(2): 257-287. http://dx.doi.org/10.1111/j.1475-679X.2006.00200.x

BENS, D.A.; HELTZER, W; SEGAL, B. (2007). The Information Content of Goodwill Impairment and the Adoption of SFAS 142. University of Arizona, DePaul University and INSEAD, Working Paper, available at: http://ssrn.com/abstract=1001744. (Last access date: September, 2012).

BIONDI, Y.; GIANNOCCOLO, P.; REBERIOUX, A. (2010). Financial Disclosure and the Board: A Case for Non-Independent Directors. Bologna University Department of Economics, Working Paper No. 689, available at: http://ssrn.com/abstract=1540027. (Last access date: September, 2012).

BORSA ITALIANA (2006). Codice di autodisciplina, March 2006. Comitato per la Corporate Governance, available at: http://www.borsaitaliana.it. (Last access date: July, 2012).

BRAMMER, S.; PAVELIN, S. (2006). Voluntary environmental disclosures by large UK companies. Journal of Business Finance and Accounting, 33(7): 1168-1188. http://dx.doi.org/10.1111/j.1468-5957.2006.00598.x

CERBIONI, F; PARBONETTI, A. (2007). Exploring the Effects of Corporate Governance on Intellectual Capital Disclosure: An Analysis of European Biotechnology Companies. European Accounting Review, 16(4): 791-826. http://dx.doi.org/10.1080/09638180701707011

CHAVENT, M.; DING, Y.; FU, L.; STOLOWY, H.; WANG, H. (2006). Disclosure and Determinants Studies: An Extension Using the Divisive Clustering Method (DIV). European Accounting Review, 15(2): 181-218. http://dx.doi.org/10.1080/09638180500253092

CHEN, C.J.P.; JAGGI, B. (2000). Association between independent non-executive directors, family control and financial disclosures in Hong Kong. Journal of Accounting and Public Policy, 19: 285-310. http://dx.doi.org/10.1016/S0278-4254(00)00015-6

COOKE, T.E. (1989). Disclosure in the Corporate Annual Reports of Swedish Companies. Accounting and Business Research, 113-124. http://dx.doi.org/10.1080/00014788.1989.9728841 
COOKE, T.E. (1991). An assessment of voluntary disclosure in the annual reports of Japanese corporations. The International Journal of Accounting, 26(3): 174-189.

COOKE, T.E. (1992). The Impact of Size, Stock Market Listing and Industry Type on Disclosure in the annual reports of Japanese Listed Corporations. Accounting and Business Research, 22(87): 229-237. http://dx.doi.org/10.1080/00014788.1992.9729440

DEUMES, R.; KNECHEL, W.R. (2008). Economic Incentives for Voluntary Reporting on Internal Risk Management and Control Systems. Auditing: A Journal of Practice and Theory, 27(1): 35-66.

DI PIETRA, R.; GRAMBOVAS, C.A.; RAONIC, I.; RICCABONI, A. (2008). The effects of board side and 'busy' directors on the market value of Italian companies. Journal of Management and Governance, 12(1): 73-91. http://dx.doi.org/10.1007/s10997-008-9044-y

ENG, L.L.; MAK, Y.T. (2003). Corporate governance and voluntary disclosure. Journal of Accounting and Public Policy, 22: 325-345. http://dx.doi.org/10.1016/S0278-4254(03)00037-1

FASB (2001). Statement of Financial Accounting Standards 142: Goodwill and Other Intangible Assets. Norwalk, CT: Financial Accounting Standards Board.

FINANCIAL REPORTING COUNCIL (2006). The Combined Code on Corporate Governance, June 2006, available at: http://www.frc.org.uk. (Last access date: July, 2012).

FORKER, J.J. (1992). Corporate Governance and Disclosure Quality. Accounting and Business Research, 22(86): 111-124. http://dx.doi.org/10.1080/00014788.1992.9729426

FRANCIS, J.; HANNA, J.D.; VINCENT, L. (1996). Causes and Effects of Discretionary Asset Write-Offs. Journal of Accounting Research, 34(3): 117-134. http://dx.doi.org/10.2307/2491429

FRANCIS, J.; NANDA, D.; OLSSON, P. (2008). Voluntary Disclosure, Earnings Quality, and Cost of Capital. Journal of Accounting Research, 46(1): 53-99. http://dx.doi.org/10.1111/j.1475679x.2008.00267.x

GARCIA-MECA, E.; SANCHEZ-BALLESTA, J.P. (2010). The Association of Board Independence and Ownership Concentration with Voluntary Disclosure: A Meta-analysis. European Accounting Review, 19(3): 603-627. http://dx.doi.org/10.1080/09638180.2010.496979

GRECO, G. (2010). Corporate governante e disclosure sui rischi in bilancio: un'analisi empirica. Rivista dei Dottori Commercialisti, 1: 1-33.

HAYN, C.; HUGHES, P.J. (2006). Leading Indicators of Goodwill Impairment. Journal of Accounting, Auditing and Finance, 21(3): 223-265.

HO, S.S.M.; WONG, K.S. (2001). A study of the relationship between corporate governance structures and the extent of voluntary disclosure. Journal of International Accounting, Auditing \& Taxation, 10(2): 139-156. http://dx.doi.org/10.1016/S1061-9518(01)00041-6 
HOLTHAUSEN, R.; WATTS, R. (2001). The Relevance of the Value-Relevance Literature for Financial Accounting Standard Setting. Journal of Accounting and Economics, 31(1-3): 3-75. http://dx.doi.org/10.1016/S0165-4101(01)00029-5

HOSSAIN, M.; HAMMAMI, H. (2009). Voluntary disclosure in the annual reports of an emerging country: The case of Qatar. Advances in Accounting, incorporating Advances in International Accounting, 25(2): 255-265. http://dx.doi.org/10.1016/j.adiac.2009.08.002

HOSSAIN, M.; PERERA, M.; RAHMAN A.R. (1995). Voluntary Disclosure in the Annual Reports of New Zealand Companies. Journal of International Financial Management \& Accounting, 6(1): 69-87. http://dx.doi.org/10.1111/j.1467-646X.1995.tb00050.x

HOSSAIN, M.; TAN, L.M.; ADAMS, M. (1994). Voluntary disclosure in an emerging capital market: some empirical evidence from companies listed on the Kuala Lumpur Stock Exchange. The International Journal of Accounting, 29(3): 334-351.

IASB (2004). IAS 36 - Impairment of Assets (revised). London: International Accounting Standards Board.

KARAMANOU, I.; VAFEAS, N. (2005). The Association between Corporate Boards, Audit Committees, and Management Earnings Forecasts: An Empirical Analysis. Journal of Accounting Research, 43(3): 453-486. http://dx.doi.org/10.1111/j.1475-679x.2005.00177.x

LAPOINTE-ANTUNES, P.; CORMIER, D.; MAGNAN, M.; GAY-ANGERS, S. (2006). On the Relationship between Voluntary Disclosure, Earnings Smoothing and the Value-Relevance of Earnings: The Case of Switzerland. European Accounting Review, 15(4): 465-505. http://dx.doi.org/10.1080/09638180601102040

LUNDHOLM, R.; MYERS, L.A. (2002). Bringing the Future Forward: The Effect of Disclosure on the Returns-Earnings Relation. Journal of Accounting Research, 40(3): 809-839. http://dx.doi.org/10.1111/1475-679x.00072

MENON, K.; WILLIAMS, J. D. (1994). The Use of Audit Committees for Monitoring. Journal of Accounting and Public Policy, 13: 121-139. http://dx.doi.org/10.1016/0278-4254(94)90016-7

MICHELON, G.; PARBONETTI, A. (2012). The effect of corporate governance on sustainability disclosure. Journal of Management and Governance, 16(3): 477-509. http://dx.doi.org/10.1007/s10997-010-9160-3

MILLER, G.S. (2002). Earnings Performance and Discretionary Disclosure. Journal of Accounting Research, 40(1): 173-204. http://dx.doi.org/10.1111/1475-679x.00043

OIC (2005). OIC 24 - Immobilizzazioni immateriali, Principio Contabile n. 24 del Consiglio Nazionale dei Dottori Commercialisti e del Consiglio Nazionale dei Ragionieri modificato dall'Organismo Italiano di Contabilità in relazione alla riforma del diritto societario. Milano: Giuffré Editore. 
PAANANEN, M. (2008). Fair Value Accounting for Goodwill under IFRS: An Exploratory Study of the Comparability in France, Germany and the United Kingdom. University of Hertfordshire, Working Paper, available at: http://ssrn.com/abstract=1275803. (Last access date: September, 2012).

PRENCIPE, A. (2004). Proprietary Costs and Determinants of Voluntary Segment Disclosure: Evidence from Italian Listed Companies. European Accounting Review, 13(2): 319-340. http://dx.doi.org/10.1080/0963818042000204742

QUAGLI, A. (2009). Dal fair value al fairy value: coerenza concettuale e condizioni di impiego del fair value negli IFRS. Financial Reporting, 1: 94-120.

QUAGLI, A.; MEINI, F. (2007). La procedura di impairment tra riflessi gestionali e politiche di bilancio. Rivista dei Dottori Commercialisti, 5: 833-859.

RAMANNA, K. (2008). The implications of unverifiable fair-value accounting: Evidence from the political economy of goodwill accounting. Journal of Accounting and Economics, 45: 253281. http://dx.doi.org/10.1016/j.jacceco.2007.11.006

RAMANNA, K.; WATTS, R.L. (2012). Evidence on the Use of Unverifiable Estimates in Required Goodwill Impairment. Review of Accounting Studies, 17(4): 749-780. http://dx.doi.org/10.1007/s11142-012-9188-5

ROYCHOWDHURY, S.; WATTS, R. (2007). Asymmetric Timeliness of Earnings, Market-to-Book, and Conservatism in Financial Reporting. Journal of Accounting and Economics, 44(1-2): 231. http://dx.doi.org/10.1016/j.jacceco.2006.12.003

SIERRA GARCIA, L.; RUIZ BARBADILLO, E; ORTA PEREZ, M. (2012). Audit committee and internal audit and the quality of earnings: empirical evidence from Spanish companies. Journal of Management and Governance, 16(2): 305-331. http://dx.doi.org/10.1007/s10997-0109152-3

TAI, B.; AU-YEUNG, P.K.; KWOK, M.; LAU, L. (1990). Non-compliance with disclosure requirements in financial statements: the case of Hong Kong companies. The International Journal of Accounting, 25(2): 98-112.

TSALAVOUTAS, I.; EVANS, L.; SMITH, M. (2010). Comparison of two methods for measuring compliance with IFRS mandatory disclosure requirements. Journal of Applied Accounting Research, 11(3): 213-228. http://dx.doi.org/10.1108/09675421011088143

TSALAVOUTAS, I. (2011). Transition to IFRS and compliance with mandatory disclosure requirements: What is the signal?. Advances in Accounting, incorporating Advances in International Accounting, 27: 390-405. http://dx.doi.org/10.1016/j.adiac.2011.08.006

VERRIEST, A.; GAEREMYNCK, A. (2009). What Determines Goodwill Impairment?. Review of Business and Economics, LIV(2): 106-128. 
WALLACE, R.S.O.; NASER, K. (1995). Firm-Specific Determinants of the Comprehensiveness of Mandatory Disclosure in the Corporate Annual Reports of Firms Listed on the Stock Exchange of Hong Kong. Journal of Accounting and Public Policy, 14(4): 311-368. http://dx.doi.org/10.1016/0278-4254(95)00042-9

WALLACE, R.S.O.; NASER, K.; MORA, A. (1994). The Relationship Between the Comprehensiveness of Corporate Annual Reports and Firm Characteristics in Spain. Accounting and Business Research, 25(97): 41-53. http://dx.doi.org/10.1080/00014788.1994.9729927

WATTS, R. (2003). Conservatism in Accounting - Part I: Explanations and Implications. Accounting Horizons, 17(3): 207-221. http://dx.doi.org/10.2308/acch.2003.17.3.207

WATTS, R.; ZIMMERMAN, J. (1990). Positive Accounting Theory: A Ten Year Perspective. The Accounting Review, 65(1): 131-156.

YEOH, J. (2005). Compliance with mandatory disclosure requirements by New Zealand listed companies. Advances in International Accounting, 18: 245-262. http://dx.doi.org/10.1016/S0897-3660(05)18012-X 